\title{
The Use of Soft-Sediment Deformation Structures As Proxies For Paleoseismic Activity And Shaking: A Review
}

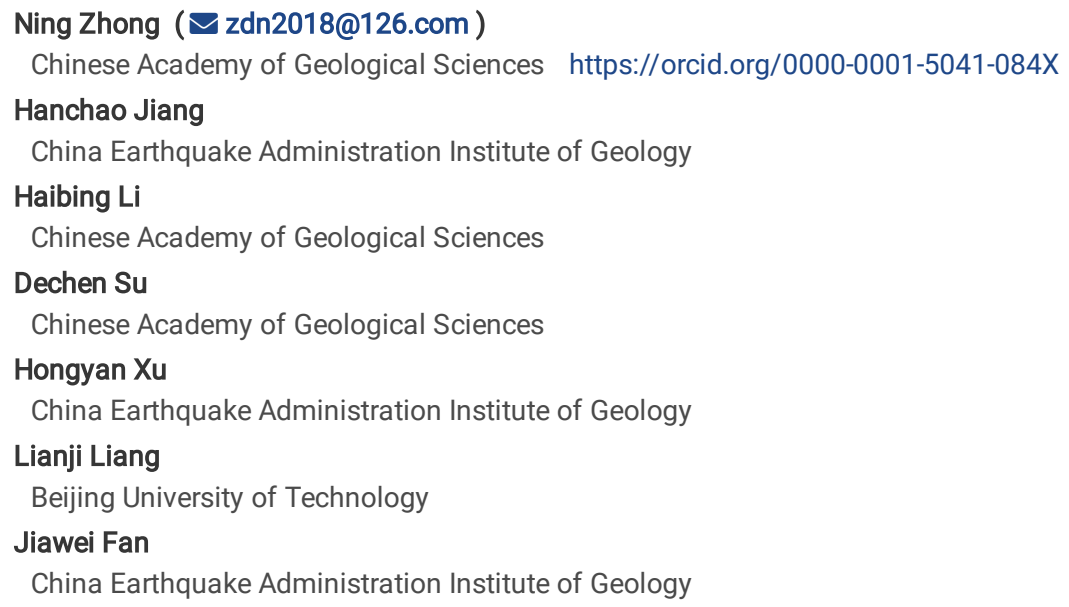




\section{Abstract}

Quantifying the magnitude of an earthquake is very important for long-term and medium-term earthquake prediction, post-earthquake emergency rescue and seismic hazard assessment. Paleoseismology is the investigation of past earthquakes in the geological record, in particular their location, timing and size. Uncertainties remain in the paleoearthquake magnitudes determined by traditional surface rupture parameters, especially because most seismic events do not result in surface ruptures. In order to address the problem of magnitude evaluation of earthquakes that did not reveal major dislocations, this paper deals with the methods used to determine the seismic shaking intensity based on the types and forms of soft-sediment deformation structures, including maximum liquefaction distance, thickness of disturbed layer, empirical formulae, and thickness of rapidly deposited sand layer. Then we discuss and analyze these methods in terms of their theoretical basis, advantages and disadvantages, accuracy, applicability and problems. We chose two case studies: first, a typical seismics-related deposit (liquefied layer and dsirupted layer) represented by a seismite in the late-Pleistocene Lake Lisan section near Masada in the Dead Sea Basin; and second, the liquefied diapir triggered by an earthquake in the late-Quaternary lacustrine sediments at Luobozhai in the upper reaches of the Minjiang River, east Tibet. The six methods listed above are employed to determine earthquake magnitudes associated with the seismics-related deposit and liquefied diapir, yielding magnitudes of 5.5-6.5 and 6-7, respectively. The combination of the six methods, provided a new and relatively convenient method for determining seismic shaking, especially in lacustrine sediments. This study can serves as a valid reference for comparing methods of calculating the magnitude of a paleoearthquake based on surface rupture parameters, and provides a better understanding of the long-term seismic activity and risk in tectonically active regions.

\section{Introduction}

Strong earthquakes cause primary and secondary effects on the natural environments. These have been codified in an Environmental Seismic Intensity (ESI) Scale 2007, which can be used together with macroseismic scales or alone, in case of inhabitated regions. This is particularly valuablefor strong earthquakes ( $M \geq 7.5)$, such as the $1999 \mathrm{M}_{\mathrm{S}} 7.6$ Chi-chi (Taiwan) earthquake (Chang et al., 2012), $2004 \mathrm{M}_{\mathrm{S}} 9.0$ Sumatra-Andaman (Indonesia) earthquake (Lay et al., 2005), $2008 \mathrm{M}_{S} 8.0$ Wenchuan (China) earthquake (Liu-Zeng et al., 2012), $2011 \mathrm{M}_{\mathrm{S}} 9.0$ Tokyo (Japan) earthquake (Sasaki et al., 2012 ), and 2015 $M_{S} 8.1$ Nepal earthquake (Yang et al., 2016) (Fig. 1). Determining the magnitude for ancient earthquakes is very important for long-term and medium-term seismic hazard assessment (Galli and Ferreli, 1995).

Paleoseismology is the investigation of past earthquakes in the geological record, especially their locations, timing and magnitudes, and focuses mainly on surface ruptures (Sieh, 1978). Nevertheless, it also benefits from the investigation of liquefaction and instantaneous deformation of landform studies. The paleoliquefaction approach in the paleoseismology focuses on soft-sediment deformation structures (SSDS) and ground failures resulting from earthquake-related liquefaction (e.g. Mccalpin and Nelson, 1996; Tuttle et al., 2019). Usually, the magnitudes of paleoearthquakes are determined by empirical relationships based on the surface rupture lengths, and maximum and average displacements per event (e.g.Wells and Coppersmith, 1994; Stirling et al., 2013). Although these methods have received much attention andmade great progresses, there are three key deficiencies stillheatedly debated. First is the inability to infer the earthquake existence when fault displacements do not reach the surface (Ran and Deng, 1999). For example, emergency surveysafter the $2013 \mathrm{M}_{\mathrm{S}} 7.0$ Lushan (Chen et al., 2014), $2015 \mathrm{M}_{\mathrm{S}}$ 6.4 Pishan (Li et al., 2016), $2015 \mathrm{M}_{\mathrm{S}} 8.1$ Nepal (Liu et al., 2015) and 2017 M 7.0 Jiuzhaigou (Xu et al., 2017) earthquakes yielded no obvious co-seismic surface ruptures, yet, these earthquakes produced a significant number of tensional ground fissures, landslides, bedrock collapses and liquefaction, in addition to the damage to buildings. What's more, only few paleoearthquake events can be identified though the trench method, and the time scale is relatively short and discontinuous (Zhong, 2017). Thirdly, much controversy remains regarding which is the magnitude threshold for ruptures reaching the surface ground. Tang et al. (2015) analyzed 56 moderate-size earthquakes worldwide occurred in the period from 1950 to 2014 AD, which caused clearly documented surface ruptures. Their analysis showed that the lowest limit of earthquake magnitude associated with surface rupture was below 6.5, most likely about 5, and even as low as 3.6 under extreme conditions (e.g. the 1966 Lompoc earthquake, with a focal depth of only $1.1 \mathrm{~km}$ ). Therefore, establishing a complementary method for evaluating the magnitude of paleoearthquakes remains an issue in paleoseismology.

In addition to ruptures, earthquakes can cause liquefaction and/or fluidization of granular solids, if their magnitude is sufficiently high ( $\mathrm{M} \geq 4.2 ; \mathrm{Galli}$, 2000); this is reflected in layers characterized by abundant SSDS (seismites, sensu Seilacher, 1969) also over long distance (van Loon et al., 2016). Lowe (1975) supposed the liquefaction is marked by the sudden breakdown of a metastable, loosely packed grain framework, the grains becoming temporarily suspended in the pore fluid and settling rapidly through the fluid until a grain-supported structure is re-established, and fluidization occurs when the drag exerted by moving pore fluids exceeds the effective weight of the grains; the particles are lifted, the grain framework destroyed, and the sediment strength reduced to nearly zero. In tectonically active regions, SSDS provide evidence for the occurrence of earthquakes (e.g., Sims, 1973; Hempton and Dewey, 1983; Allen, 1986; Galadini et al., 1995; Marco and Agnon, 1995; Moretti et al., 1999; Neuwerth et al., 2006; Moretti and Sabato, 2007; Suter et al., 2011; van Loon and Pisarska-Jamroży, 2014; Jiang et al., 2016; van Loon et al., 2016; Liang et al., 2018; Salomon et al., 2018; Zhong et al., 2019). As early as forty years ago, researchers had started to analyze and discuss the relationship between SSDS and earthquake magnitudes. Commonly used methods and parameters derived from the SSDS include the thickness of disturbed beds (Hibsch et al., 1997; Rodriguez-Pascua et al., 2003), the maximum liquefaction distance (Kuribayashi and Tatsuoka, 1975; Liu and Xie, 1984; Ambraseys, 1988; Galli and Ferreli, 1995; Papadopoulos and Lefkopoulos, 1993; Obermeier, 1996; Galli, 2000; Obermeier et al., 2002; Maurer et al., 2015; Qiao et al., 2017), the types of SSDS (Rodriguez-Pascua et al., 2000; Neuwerth et al., 2006; Berra and Felletti, 2011), and the thickness of rapidlydeposited sand layers (Moernaut et al., 2014). However, these methods have some disadvantages, as follows. (1) Besides earthquakes, many processes can produce SSDS, such as gravity slides (Owen and Moretti, 2008; van Loon, 2009); overloading (Moretti and Sabato, 2007; Owen and Moretti, 2008), rapid sedimentation (Lowe, 1975; Postma, 1983), channel erosion (Dasgupta, 1998), storm waves (Molina et al., 1998; Alfaro et al., 2002), and ice over-riding permafrost (Anketell and Dzulynski, 1970; Vandenberghe, 1992; Zhong et al., 2020a). Consequently, it is necessary to determine the cause of eachdeformation feature. However, liquefaction can be induced by 21 triggers, earthquake only represents the one of

Page $2 / 21$ 
these triggers (Shanmugam, 2016). What's more, considering that the deformation mechanism of SSDS is complicated, there are still uncertainties in the interpretation of its genesis and trigger mechanism, especially the fluvial and lacustrine deposits with complex sedimentary processes (Zhong et al., 2020b). Therefore, it is very important to determine the origin and trigger mechanism of SSDS. (2) The nature of the driving force, the sediment rheology, deformation mechanism and timing of deformation relative to sedimentation, can affect the final morphology and deformation style of SSDS (Owen, 1987). (3) The epicenter distance, depth of hypocenter, and intensityand duration of seismic shaking can also affect the final morphology and types of SSDS (Obermeier, 1996). (4) Determination of the seismic shaking using SSDS also depends on the regional geology, tectonic setting, sedimentary environment, sedimentary age, and in particular the grain-size distribution, water content and consolidation degree of the sediments (Owen and Moretti, 2011; Moretti et al., 2016; Zhong et al., 2017). Therefore, the relationships between the types and forms of SSDS and earthquake magnitudes need further researches. Here, we summarize and analyze the research methods employed in the SSDS investigations, including their theoretical basis, advantages and disadvantages, accuracy, applicability and problems.

This paper aims to: (1) summarize the methods for determining seismic shaking intensities using SSDS; (2) analyze the applicability, advantages and disadvantages of each method; and (3) develop a new method for determining shaking intensities. The results of our work can provide a better understanding of the regional seismic risk.

\section{Previous Studies And Proposed Methods}

Determining earthquake magnitude or seismic shaking based on SSDS includes observations of the types and forms of SSDS, maximum liquefaction distance, thickness of a disturbed layer, empirical formulae, and thickness of an rapidly-deposited sand layer (Table.1). Among these, the most commonly used methods are the maximum liquefaction distance (Qiao et al., 2017) and the deformation type (Rodriguez-Pascua et al., 2000). Historical liquefaction method (Sims, 1975) and the thickness of the disturbed layer (Hibsch et al., 1997) are based on the liquefaction deformaton intensity and its relationship with the deformation amplitude of the SSDS layer and the seismic shaking, respectively. These methods only provide the lower limit of seismic shaking, and are used less frequently. The empirical formula (Rodríguez-Pascua et al., 2003) and the thickness of rapidly-deposited sand layer (Moernaut et al., 2014) methods are based on the thickness of the SSDS layer and its relationship with the thickness of the overlying sand layer and the earthquake magnitude, respectively. Due to the complexity of SSDS deformation mechanisms and lacustrine sedimentation processes, this method is still under investigation. The method also has strict requirements on the thickness of the deformed layer $(\leq 15 \mathrm{~cm})$ and thickness of the rapidly-deposited sand layer ( $\leq 50 \mathrm{~cm})$ (Zhong et al., 2020c), which limits the scope of its use. In the following paragraphs, we will analyze the applicability, and advantages and disadvantages of each method

\section{Historical liquefaction cases for determining lower boundary curve for liquefaction occurrence}

Controversy remains regarding the lowest limit of earthquake magnitude that can cause liquefaction. Some researchers initially believed that a $\mathrm{M}_{\mathrm{S}} 2-3$ earthquake was large enough to trigger liquefaction (e.g., Seed and Idriss, 1971). Later, Scott and Price (1988) proposed that earthquakes with magnitude smaller than 5 do not cause significant liquefaction of sediments. Valera et al. (1994) suggested that the threshold magnitude to induce liquefaction effects in the most susceptible gravel deposits is about 7 (e.g. in the 2008 Wenchuan $M_{S} 8.0$ earthquake, the liquefaction of gravelly soils accounted for $80-85 \%$ of all liquefaction points, see Cao et al., 2010), whereas the threshold magnitude for sands is about 5.5. Marco and Agnon (1995) proposed that the triggering of liquefaction occurs only for earthquake magnitudes larger than 4.5; these values are consistent with the historical case studies (Kuribayashi and Tatsuoka, 1975; Youd, 1977; Galli, 2000). Many researchers (e.g. Allen, 1986; Audemard and De Santis, 1991; van Loon et al., 2016) have suggested that Richter magnitudes larger than 5 are required to produce significant liquefaction effects in near-surface, water-saturated, semi-consolidated to unconsolidated sediments. The duration of ground shaking during seismic events of smaller magnitude $(M<5)$ is often insufficient to cause liquefaction.

An MMI (Modified Mercalli Intensity Scale) of about VI is the threshold for widespread development of small-scale SSDS features such as folds, pseudonodules, contorted laminations and recumbent folds (Sims, 1975). Although liquefaction effects have occurred at MMI values as low as $\mathrm{V}$ and $\mathrm{VI}$ (Galli, 2000 reports lo 5-6 MCS, Mercalli Cancani Sieberg scale), Keefer (1984) suggested that the lowest shaking at which liquefaction-induced features can become common is VII. Monecke et al. (2004) found that lake sediments are only affected if they are situated within an area that underwent ground shaking of at least shaking VI to VII. Small-scale SSDS, such as disturbed and contorted laminations as well as liquefaction structures (e.g. dish structures), are generated by earthquakes when $M=5-5.5$ (Monecke et al., 2004, 2006). When an earthquake causes liquefaction and/or fluidization of water-saturated sediments, the magnitude could be $\mathrm{M} \geq 5$ or the $\mathrm{MMI}$ greater than $\mathrm{Vl}$. The advantage of the historical liquefaction method for assessing seismic shaking is its convenience, speed, and wide range of applicability. The disadvantages are that the accuracy is limited and it only provides the lower limit of seismic shaking. Therefore, historical liquefaction method can be used only as a preliminary seismic shaking estimation method.

\section{Maximum liquefaction distance for determining earthquake magnitude}

The sand or soil liquefaction and water ejection features caused by earthquakes show a clear correlation with the magnitude and epicenter distance (Kuribayashi and Tatsuoka, 1975; Qiao et al., 2017). The larger the earthquake magnitude, the wider the distribution of liquefied sites (Papadopoulos and Lefkopoulos, 1993). Paleoearthquake magnitudes have been calculated based on sand-layer liquefaction data for modern and historical earthquakes (Qiao and Guo, 2013). The key is first to establish the location of the epicenter, and then to determine the location of the farthest liquefaction from the epicenter (Qiao et al., 2017). This requires identification of the location of liquefaction deformation that is the furthest from the seismogenic fault that induced the 
earthquake, when undertaking geological field surveys and paleoearthquake research. Kuribayashi and Tatsuoka (1975) have been commended for their comprehensive compilation of the occurrence and distribution of liquefaction during Japanese earthquakes of the past century (1872-1968), and they produced the first map revealing the relationship between the maximum epicentral distance of liquefied sites (R) and magnitude (M) for at least 44 earthquakes ( $M$ > 5.3) and liquefied sites (Fig. 2). Youd (1977) compiled data for 14 earthquakes ( $M$ > 5.3) from 1897 to 1976 in the USA, India, New Zealand and Chile; their data support the conclusion of Kuribayashi and Tatsuoka (1975) that there is a maximum distance beyond which liquefaction is not likely to occur for an earthquake of a given magnitude. Liu and Xie (1984) compiled sand-bowls and sand-emission data for the 900 years before 1995 , and established a relationship between magnitude and maximum epicentral distance to liquefied deformation in China. Ambraseys (1988) re-examined the 44 events analyzed by Kuribayashi and Tatsuoka (1975) and eliminated 5 cases, then added the further 14 cases reported by Youd (1977) from other parts of the world, 6 by Davis and Berrill (1983) and 7 by Fairless and Berrill (1984), as well as 70 new cases; in total 137 earthquakes known to have caused ground failures due to liquefaction were analyzed. Ambraseys (1988) then established a relationship between maximum epicentral distance of liquefied sites R (km) and moment magnitude M. Galli (2000) updated the Italian catalog of liquefaction (Galli and Meloni, 1993; Galli and Ferreli, 1995) by means of new systematic historical researches. This database, permitted the construction of empirical relationships between the epicentral parameters of the earthquake (Io, Ms, and Mw) and the distance of the observed liquefaction for 317 cases related to 61 different earthquakes in Italy since 1117 . The triggering events range from intensity (MCS) 5.5 to 11, from magnitude (Ms) 4.2 to 7.5, and magnitude (Mw) 4.83 to 7.46. Papadopoulos and Lefkopoulos (1993) propose a slight modification of the M/R and M/R relations suggested by Ambraseys (1988). Subsequent revision and addition of further data by Obermeier (1996) and Obermeier et al. (2002) has yielded other widely-used diagram showing the relationship between SSDS and earthquake magnitude. Qiao et al. (2017) produced a detailed plot of maximum liquefaction distance and earthquake magnitude (Fig. 3) which shows an obvious relationship between the earthquake epicenter and the farthest surface liquefaction. We can use the R-M map to estimate earthquake magnitude based on the largest distance between the observed liquefaction points and the earthquake epicenter (or responsible fault) in the field.

Conversely, in the field, it is often difficult to determine whether the observed liquefaction deformation may be the farthest from the epicenter. Nevertheless, the R-M map (Fig. 3) can still be used to estimate the magnitude of the earthquake, because it gives a reasonable range of paleoearthquakes magnitudes triggered by active faults that may have formed SSDS, and once the responsible fault has been identified, the R-M map (Fig. 3) can be applied. The epicenters of paleoearthquake should be distributed along the fault, similarly to epicenters of modern earthquakes. When the epicenter of a paleoearthquake is unknown, we can also project the vertical distance from the furthest liquefaction deformation record (or the location of the liquefied deformation section) to the seismogenic fault onto the R-M map; this provides an estimate of the range of the paleoearthquake magnitude. We note that the R-M map only can provide a quasi-quantitative paleoearthquake magnitude, and cannot be as accurate as modern earthquake magnitudes obtained by seismic wave measurements.

\section{Thickness of disturbed layers for determining seismic shaking}

Some attempts (e.g. Sims, 1975) have been made to establish a relationship between seismic shaking and thickness levels, based on SSDS. Guiraud and Plaziat (1993) measured the degree of deformation in seismites observed within the Bima Sandstone Formation of the Lower Cretaceous Beune Basin, Northeastern Nigeria. Hibsch et al. (1997) compared the distribution of coseismic deformation thicknesses (disturbed or contorted layer) and the distribution of historical seismic shaking in the Holocene fluvial-lacustrine sediments of the northern Quito Basin, leading to the proposal of a new method of paleoseismic analysis which achieved relatively good for seismic shaking over VI. Fig. 4 shows the historical seismicity of Quito and attribution of seismic shaking (MMI) to the deformation levels. Considering that the sedimentological characteristics have a greater control than the layers thickness, then for layers with a similar lithology (grain-size, sorting, petrology, compaction, etc.), a stronger seismic shaking should result in a thicker disturbed layers. Disturbed layers thicknesses of $0-8 \mathrm{~cm}$ and $27-53 \mathrm{~cm}$ could tentatively correspond to seismic intensities of $\mathrm{VI}$ and XI, respectively. It is important to note that the disturbed layers occurred at the water/sediment interface, and are identified by the following features: constant thickness of contorted and disrupted layers not related to slumps; horizontal post-earthquake deposits showing the same lithology as that of the deformed horizon (Hibsch et al., 1997). Considering the paucity of the statistical data, and the lack of experimental validation, the accuracy of the disturbed layers thickness methodology is limited. In addition, this method does not consider the effect of the sedimentary layer on seismic waves (amplitude and travel time) (Li et al., 1991). In a specific succession, earthquake-induced seismic waves will deform the same layer (or set of layers), possibily independent of their magnitude. A strong earthquake may deform only a thin layer, and a weak earthquake may deform a thick unit, which need further research.

SSDS can evolve in one liquefiable layer (silt), or concurrently in two (silt and sand), or even in three layers (silt, sand and gravel), as a function of the energy involved (Rodríguez-Pascua et al., 2010). Rodríguez-Pascua et al. (2010) proposed a new methodology (DDI, degrees of intensity deformation) to estimate the intensity of SSDS. Through comparative analysis of multiple SSDS sections in the Tierras Blancas Basin, Rodríguez-Pascua et al. (2010) established a regional paleoseismic isoline by the DDI method, and inferred the seismogenic source of this paleoearthquake. This method can therefore benefit regional seismic hazard assessment. Based on the Kelvin-Helmholtz instability mechanism, Lu et al.(2020) modeling the relationship between soft deposition deformation structure and peak ground acceleration (PGA), and constrain the magnitudes of the six paleoearthquakes (seismites) with intensities of VII (0.18g), VI. (0.13g), VI (0.09g), VII (0.18g), VI (0.09g), and VII (0.18g) as Mw 5.6, Mw 6.1, Mw 6.2, Mw 7.1, Mw 6.0, and Mw 6.9, respectively, which are in line with recorded historic magnitudes.

\section{Empirical formulae for determining earthquake magnitude}

Rodríguez-Pascua et al. (2003) found that the frequency-thickness distribution of 73 seismites obeys an exponential law, and that the "b" value of this distribution is the same as the "b" value for the seismicity of the area(b is defined by the Gutenberg-Richter law, and reflects the proportional relationship 
between large and small earthquakes). In addition, they compared the deformation caused by modern and historical earthquakes in Spain with the deformations caused by paleoearthquakes, and found very similar characteristics. Then they established an empirical relationship between the seismicsrelated deposit (liquefied layer and disrupted layer) thickness of the studied sediments and the earthquake magnitude, yielding the empirical formula $\mathrm{M}=$ $T / 3+3.83$, where $T$ (in $\mathrm{cm}$ ) is the thickness of the seismics-related deposit and $M$ is the magnitude. Three zones characterized by distinctive styles of deformation can be distinguished in a fully-developed seismics-related deposit: an uppermost fluidization zone, an intermediate zone of ductile-fragile deformation (breakage and fragmentation of lamina), and a lower zone showing features typical of ductile deformation (folding of lamina). This lower zone overlies undeformed laminae (Rodríguez-Pascua et al., 2003).

This characteristic seismics-related deposit structure was first defined by Marco et al. (1994) for laminated sediments of the Pleistocene Lisan Formation in the Dead Sea region (Middle East). Marco and Agnon (1995) suggest that the seismics-related deposit are composed of fine-grained matrix-supported texture and tabular laminated fragments, underlain by asymmetrical and recumbent folds, and overlain by undeformed sand layers. Marco and Agnon (2005) changed the term "seismics-related deposit" to "breccia-layers", and interpreted them as seismites. Undisturbed laminated layers between these breccia layers represent inter-seismic intervals. To separate observations from interpretations, "intraclast" refers to the clasts that were reworked from within the sedimentary section; Agnon et al. (2006) replaced the term "breccia-layers" with "intraclast breccia layers" and stressed that the term "breccia" refers to the texture of the deposit. In addition, they considered the formation of intraclast breccias, proposing that earthquakes are the main mechanism. The Dead Sea intraclast breccias have many similarities to seismites described in a lacustrine environment (Zhong, 2017), as well as glacial deposits (Davenport and Ringrose 1987). Based on field observations and research experience, we propose that the seismics-related deposit (named breccia layer by Agnon et al., 2006) should comprise a liquefied or fluidized layer and overlying detrital layer, but should not include the overlying undeformed sand layer with a grain size change in vertical section.

No clear standard has been defined for the thickness of the seismics-related deposit (Rodriguez-Pascua et al., 2003), thus limiting its application. Many empirical data show that the magnitude is not strictly linear with the logarithm of earthquake frequency (Fu, 1997), and a robust error estimation and confidence interval calculation is needed for "b" values. Mugnier et al. (2011) found that the lithology, grain size, sedimentary environment and acceleration can all influence the thickness of seismites, and also the number of individual shocks and number of cycles (earthquake recurrence cycle) can affect the final thickness of the deformed layer. Meanwhile, numerical simulations indicate that, firstly, deformation intensity increases with increasing ground acceleration and decreasing layer thickness; and secondly, the duration of the earthquake affects the deformation geometry, rather than the deformation amplitude (Wetzler et al., 2010). Therefore, the relationship between coseismic shaking and thickness of the seismics-related deposit is very complex and is not single-valued (Mugnier et al., 2011); as such, one should be very careful in applying the empirical formula.

\section{Types of SSDS for determining earthquake magnitude}

In water-saturated and unconsolidated sediments, different seismic shaking and deformation mechanisms (liquefaction, fluidization, thixotropy etc.) can result in different types of deformation structure. For example, gravity and liquefaction can gradually form load, flame, ball-and-pillow and pillow-bed structures. Firstly, the superposition of coarse-grained sand (heavy) on fine-grained sand (light) is analogous to gravitational instability (Anketell et al., 1970), allowing coarse-grained sediment to sink into fine-grained sediment when the fine-grained (underlying) material liquefies, resulting in load casts. Secondly, as a load cast develops, the underlying, finer sediment compensates its loss of space with upward intrusions forming flame structures. Thirdly, at the base of the source layer, horizontal motion generates horizontal shear stress in the over-pressurized fine-grained layer, and causes the laminae to convolute within the clay to form contorted layer (Suter et al., 2011). Fourthly, with stronger and/or longer seismic shaking, the heavy sand completely sinks into the light sand, forming pseudo-nodules (Anketell et al., 1970) and ball-and-pillow structures (Owen, 1987), and eventually forming pillow-bed structures (Qiao and Li., 2008). Sims (1973) suggested that the evolution of the load cast phenomenon towards pseudonodule formation may be an indication of stronger and/or longer seismic shaking. Under identical conditions (i.e. in the same sedimentary environments), the seismic shaking required to create balland-pillow structures should be greater than that required to create load cast and flame structures, while the shaking needed to create pillow beds should be larger than that needed to generate the ball-and-pillow structures (Owen, 1987).

Rodríguez-Pascua et al. (2000) summarized the various types of SSDS and their relationships with earthquake magnitudes, suggesting that seismicsrelated deposit, pseudonodules and ball-and-pillow structures correspond to magnitudes of 5.5-6.5, 6.5-8 and 6-8, respectively (Fig.5). Taking into account the distances to seismogenic faults, Neuwerth et al. (2006) tentatively postulated that the earthquake magnitude required to generate SSDS is 5-7. Berra and Felletti (2011) concluded that an earthquake should have a Richter magnitude of between 6 and 8 if it is to be capable of generating ball-andpillow structures or irregular, contorted stratification. Qiao and Guo (2013) used the relationship between earthquake magnitude and the maximum distance from epicenter established by Liu and Xie (1984) and Obermeier (1996), and suggested that liquefaction or fluidization deformation (droplets and a homogenized layer) in early Jurassic lacustrine sandstones in the Wuqia region of the SW Tianshan Mountains may have recorded paleoearthquake magnitudes ranging from M 6.5 to 7. In addition, a large number of load and ball-and-pillow structures have been reported from a liquefied deformed layer with the same age (Qiao and Guo, 2013). Zhong et al. (2017) proposed that the load and ball-and-pillow structures were triggered by earthquakes with magnitudes of 6-7. It is possible to obtain the seismic shaking through comparative analysis of similar types of SSDS triggered by earthquakes in the same sedimentary environments with similar lithology.

\section{Thickness of rapidly deposited sand layer for determining earthquake magnitude}

The $M_{S} 8.0$ Wenchuan earthquake struck on 12 May 2008, triggering more than 190, 000 landslides and collapses along ridges and hillslopes of the Longmen Shan (Sichuan, China) (Xu et al., 2014). These detrital materials still remain in the hillslopes and valleys of the earthquake area. The transfer of a

Page 5/21 
large amount of landslide material from the hillslopes to the river network resulted in a large number of dams and associated lakes that formed immediately after the Wenchuan earthquake (Fan et al., 2012). Wang et al. (2015) used suspended sediment ( $<0.25 \mathrm{~mm}$ ) concentration measurements from several rivers (Minjiang River, Fujiang River and Tuojiang River) in the epicentral area to analyze the evolution of suspended sediment flux; their results showed suspended sediment discharge increased by factors of 3-7 after the Wenchuan earthquake relative to $2006-2007$ levels. Furthermore, ${ }^{10}$ Be mixing budgets indicate that the sediment flux of the $0.25-1 \mathrm{~mm}$ size fraction increased by up to six-times following the Wenchuan earthquake (Wang et al., 2017). Across the Longmen Shan, at the present rate of post-earthquake fluvial export, Wang et al. (2015) estimate that it will take $33 \pm 24$ yr to remove all material $<0.25 \mathrm{~mm}$ delivered by coseismic landslides, and coarse sediment ( $>0.25 \mathrm{~mm}$ ) will take about $1000 \mathrm{yr}$. The entrance of the Zipingpu reservoir at the highest water level is $\sim 2 \mathrm{~km}$ downstream from the epicenter of the 2008 Wenchuan earthquake, which can captures a significant portion of the landslide material associated with the 2008 Wenchuan earthquake. The deposition record in the Zipingpu reservoir core shows the grain size and magnetic susceptibility have an abrupt coarsening (increasing) and upward fining (decreasing) after the 2008 Wenchuan earthquake (Zhang et al., 2019). However, these changes (grain size and magnetic susceptibility) were delayed until 2 years after the event. Based on this delay, Zhang et al. (2019) emphasized the importance of the interplay between a major earthquake and the prevailing monsoonal climate, highlighting the central role of runoff as an erosional agent in removing earthquake-triggered landslide material and in creating a corresponding depositional signal of the earthquake. After the 2008 Wenchuan earthquake, the large quantities of dust in many of the landslides and collapses also caused frequent dust storms. This dust accumulated on local roads, reaching several centimeters in thickness (Liang and Jiang, 2017). Based on the geochemistry, quartz particle scanning electron microscopy and grain size, Jiang et al. (2014) proposed that lacustrine sediments in east Tibet were transported by wind and trapped in lakes; most of this material originated from local windblown sediments. From these results it can be hypothesized that large earthquakes in east Tibet might have caused widespread rockfalls and landslides, leading to exposure of fine-grained sediments that have accumulated on mountain slopes before undergoing aeolian transport into the lake. Interestingly, post-seismic vegetation recovery at landslide sites indicates that the Wenchuan earthquake's impact on regional post-seismic landslide frequency may disappear within two decades of a major event (Yang et al., 2018). This implies that the amount of detrital material released in the area gradually decreases after an earthquake.

The above discussion shows that, strong seismicity $(M \geq 5)$ can cause not only liquefaction and/or fluidization of water-saturated sediments, resulting in various types of brittle and/or ductile deformation, but can also generate a large amount of debris (landslides, dust, etc.), which is rapidly transported into lakes by wind and/or rivers, and deposited as a series of turbidites (Howarth et al., 2012; Moernaut et al., 2014; Archer et al., 2019; Fan et al., 2020; Molenaar et al.,2021). Seismic shaking may also trigger sedimentary instabilities on the steep slopes of lake basins (Katz et al., 2009) or lake seiches (Beck, 2009; Avşar et al., 2014), resulting in mobilized masses at proximal sites (i.e., slides, slumps, debris flows) (Zhang et al., 2014) and deposition from induced turbidity currents at distal sites (i.e., seismoturbidites). When an earthquake occurs, pre-existing unconsolidated lake deposits (below the event horizon) may deform and generate various SSDS (Fig. 6), followed by the deposition of medium- to coarse-grained particles released by earthquake-induced processes to form a so-called event layer (rapidly-deposited sand layer formed by material supplied due to effects of the seismic shock) above the event horizon (Jiang et al., 2014; Zhong et al., 2020c) (Fig. 6). Event layers were found to have varying thicknesses in the upper part of the SSDS in the Lixian lacustrine sediments, east Tibet (Jiang et al., 2017). In these SSDS, the grain-size and magnetic susceptibility repeatedly show abrupt coarsening and upward fining, probably because frequent earthquakes have generated a large amount of debris in the lacustrine sediments of the present study area, resulting in an abrupt increase in the terrigenous flux of coarse-grained (magnetic material) in the Lixian dammed paleo-lake (Jiang et al., 2016, 2017). Such earthquakes $(M>5.0 / 5.5)$ have not always resulted in the formation of SSDS in lacustrine sediments, perhaps due to their greater distance from the epicenter (Owen and Moretti, 2011) or the higher sand/mud ratio of lacustrine sediments (Jiang et al., 2017); nevertheless, they can still generate a large amount of debris within the lake basin. A positive correlation between the thickness of the seismites and the seismic shaking has been identified (Hibsch et al., 1997; Rodríguez Pascua et al., 2003), but it remains unclear whether there is a correlation between the thickness of the event layer (post-seismics deposit) and the seismic shaking.

Keefer (1984) produced the first map to show the area affected by landslides during earthquakes of different magnitudes for 40 historical world-wide earthquakes covering the years 1811 to 1980 . The correlation between magnitude $(M)$ and landslide distribution shows that the minimum magnitude likely to trigger landslides is $M \approx 4.0$. This limit was subsequently revised and constrained with further data by Rodríguez et al. (1999) and Xu et al. (2014). Bommer and Rodríguez (2002) presented data for earthquake-triggered landslides in Central America but noted that their characteristics can be compared with global relationships between the area of landslides and earthquake magnitudes (Fig. 7a). Malamud et al. (2004) confirmed the results of Keefer (1984) and proposed that the minimum earthquake magnitude required to trigger landslides is $\mathrm{Mw}=4.3 \pm 0.4$. Under the same geological conditions, the stronger the earthquake, the larger the area and volume of landslides. A strong earthquake can induce tens of thousands of landslides, especially in alpine valleys (Xu et al., 2014; Zhang et al., 2017).

By establishing a high-resolution Holocene seismic history of the Dead Sea Transform, Migowski et al. (2004) found the thickness of the disturbed layer has reasonable correlation with magnitude. This disturbed-layer sedimentary pattern is punctuated by successions of disturbed sedimentary structures that typically consist of aragonite fragments "floating" in a silty detrital matrix without any indication of transport. Furthermore, Moernaut et al. (2014) found that a turbidite's spatial extent and thickness are a function of the local seismic shaking and can be used for reconstructing paleo-intensities. They also established a linear correlation between cumulative turbidite thickness and seismic shaking of the causative earthquake. Theoretically, a larger magnitude earthquake produces more debris (landslide, dust etc.) and a thicker rapidly deposited sand layer (event layer) in local water bodies. Initial conditions should also be considered: for example, the degree of gravitational instability of the sedimentary body; textural parameters; depth of sliding surface; etc.

To assess this theory, we assimilated data on the thicknesses of rapidly deposited sand layers from 32 historical world-wide earthquakes (France, Turkey, New Zealand, and Chile) covering the years 181 to 2010. For more details on determining the genesis and thickness of sand layers, based on abnormal changes in sedimentary indexes, see Avşar et al. (2014) and Jiang et al. (2014). Next, we established a linear correlation between the cumulative sand layer 
thickness and magnitude of the causative earthquake (Fig. 7b), yielding a residual mean square of 0.40 . Correlation between magnitude (M) and cumulative sand layer thickness shows that the minimum thickness likely to be affected by debris material in a sand layer increases from approximately zero at $\mathrm{M}=$ 5.0 to $50 \mathrm{~cm}$ at $\mathrm{M}=8.0$. A cumulative sand layer with a thickness of $1 \mathrm{~cm}$ corresponds to earthquake magnitudes of $\sim 4.0-6.0$. A cumulative sand layer with a thickness of $10 \mathrm{~cm}$ corresponds to earthquake magnitudes of $\sim 5.8-8.4$. If the debris (landslide, dust etc.) in the lake drainage basin is induced by earthquakes, and is transported into the lake, then the correlation between the cumulative sand layer thickness and the magnitude can be used to determine the magnitude or shaking of the seismic event under study.

Considering that the denudation mechanism of debris in a lake drainage basin is complicated, and that other factors such as provenance, topography, meteorological conditions and hydrodynamic conditions can also affect the sediment transport, we note that most lake sediments comprise mixtures of sediment populations derived from different sources and transported to the site of deposition by different mechanisms. Therefore, it is difficult to assess the true significance of variations in sediment properties, especially when considering that the provenance of lake sediments may also be influenced by extreme weather events (e.g. rain storms, sand storms, etc.). Consequently, we propose that components of the lake sediments should be separated (see the end-member modeling method: Weltje, 1997), by distinguishing tectonic and climatic components, when studying a seismic event layer and its thickness, for the purpose of determining the seismic shaking. Admittedly, this method is only based on statistical results of the data, it require more data support and further examination. Therefore, the method of rapidly deposited sand layer thickness can only be used to gain a rough magnitude estimate with limited accuracy, and needs to be compared with alternative methods of verifying seismic shaking.

\section{Other methods}

Two independent methods for determining earthquake magnitude are numerical simulations and shaking table experiments. Wetzler et al. (2010) carried out field observations in the Lisan Formation sediments (Dead Sea) and numerical simulations based on peak ground acceleration and its relationship with deformed layer thickness and deformation morphology. Their results reveal that deformation morphology is controlled by ground acceleration and deformed layer thickness. Shaking table experiments are not only limited by the available instruments and equipment, but are also affected by the sediment materials, grain size, porosity and permeability during the experiment (Shen, 2014). Considering the complex rheologies involved, and because the developing structures are impossible to observe in sediments (Harrison and Maltman, 2003), shaking table experiments are used less frequently than other methods mentioned above.

The other method is based on geotechnical engineering techniques at sites of marginal liquefaction (a critical state of liquefaction), to constrain the peak accelerations as a function of epicentral distance: these accelerations can then be compared with predictions from seismological models, and used for back-calculating prehistoric magnitudes (Obermeier, 1996, 1998).

\section{Case Studies}

\section{Lake Lisan section}

The Dead Sea Basin is a pull-apart graben enclosed between two overlapping segments of the active and seismogenic Dead Sea Fault (Fig. 8a, b), at the boundary between the Arabian plate and the Sinai plate (Galli, 1999 and reference therein). Tens of earthquakes with $M>6$ have occurred along the Dead Sea Fault during the past $~ 3 \mathrm{ka}$ and have been the object of studies by several authors (Ambraseys and Finkel, 1991; Ambraseys, 2009; Lu et al., 2017). The two strongest seismic shocks recorded in modern times occurred at the Gulf of Aqaba (southernmost Dead Sea) in 1995, with Mw = 7.3 (Klinger et al., 1999; Galli, 1999), and in the Jericho Valley in 1927, with $M=6.2$ (Shapira et al., 1993). Most of the Lisan Formation is made by laminated sediments of ancient Lake Lisan, composed of alternating laminae of authigenic aragonite and detritus; the latter consists of fine-grained calcite, dolomite, quartz and clay. Undisturbed laminated layers between deformed layers have been interpreted as interseismic intervals (Amotz and Marco, 1995). The deformed, layers in the lacustrine Late Pleistocene Lisan Formation and Holocene Dead Sea sediments comprise an almost continuous 70 ka paleoearthquake record in the Dead Sea Basin (Marco et al., 1996). Based on the historical earthquakes, current seismic activity near the Dead Sea, a syndepositional normal fault in the Lisan Formation (near Masada) unconformably overlain by undisturbed layers, sedimentary markers (e.g. fragment-supported texture, etc.) and the SSDS (folded layer), Marco and Agnon (1995) interpreted such layers as seismites formed by fluidization of the upper sediment layers at the bottom of the lake during strong earthquake shaking, representing strong seismic events $(M \geq 5.5)$.

To better constrain the magnitudes associated with the mixed layers in the Lake Lisan section (Fig. 8c), we use the six methods reported above to determine the magnitude or shaking of these seismic events. These yield the following results: (1) the minimum earthquake magnitude required to induce liquefaction should be higher than 5; (2) the distance of the Lake Lisan section to the syndepositional faults at Masada is < $5 \mathrm{~km}$ (Marco and Agnon, 1995), which according to the R-M map (Fig. 3) yields earthquake magnitudes of 5.2-6.8; (3) applying the relationship between seismic paleointensities and thicknesses of the paleoseismic horizons (Fig. 4) to the $13 \mathrm{~cm}$-thick disturbed layer in the Lake Lisan section (Fig. 8c) yields a corresponding seismic shaking of $\mathbb{\varangle - \varangle ;}$; (4) applying the empirical formula $(\mathrm{M}=\mathrm{T} / 3+3.83)$ to the $10 \mathrm{~cm}$-thick seismics-related deposits in the Lake Lisan section yields a corresponding earthquake magnitude of 6.83; (5) applying the relationship between mixed (breccia) layers and earthquake magnitudes (Fig. 5) yields corresponding earthquake magnitude of 5.5-6.5 (Table. 2); and (6) applying the relationship between earthquake magnitude and rapidly deposited sand layer thickness (Fig. 7b) to the $2 \mathrm{~cm}$-thick sand layer above the seismics-related deposit in the Lake Lisan section yields a corresponding earthquake magnitude of 4.2-6.6. Therefore, we suggest that the seismics-related deposit presented in Fig. 7 of the Lake Lisan section near Masada in the Dead Sea graben correspond to earthquake magnitudes of 5.5-6.5 (Table 2). 
Table 1

Comparative analysis of six methods for determining the magnitude of paleoearthquake.

\begin{tabular}{|c|c|c|}
\hline Method & Advantage & Shortage \\
\hline $\begin{array}{l}\text { Proposed } \\
\text { methods }\end{array}$ & Wide applicability; convenient and efficient & $\begin{array}{l}\text { Only the lower limit of magnitude can be given, and } \\
\text { have a large error. }\end{array}$ \\
\hline $\begin{array}{l}\text { Maximum } \\
\text { liquefaction } \\
\text { distance }\end{array}$ & Wide applicability; higher accuracy & The location of seismogenic faults is uncertain. \\
\hline $\begin{array}{l}\text { Thickness of } \\
\text { disturbed } \\
\text { layers }\end{array}$ & Wide applicability; convenient and efficient & $\begin{array}{l}\text { The definition of disturbance layer thickness is } \\
\text { indeterminacy, and have a large error. }\end{array}$ \\
\hline $\begin{array}{l}\text { Empirical } \\
\text { formulae }\end{array}$ & Convenient and efficient & $\begin{array}{l}\text { The definition of mixed layer thickness is } \\
\text { indeterminacy, and only suitable for deformation } \\
\text { structures with thickness less than } 15 \mathrm{~cm} \text {. }\end{array}$ \\
\hline $\begin{array}{l}\text { soft-sediment } \\
\text { deformation } \\
\text { structures }\end{array}$ & Wide applicability; higher accuracy & $\begin{array}{l}\text { It is necessary to determine the origin and types of } \\
\text { soft sediment deformation structures }\end{array}$ \\
\hline $\begin{array}{l}\text { Thickness of } \\
\text { rapidly } \\
\text { deposited } \\
\text { sand layer }\end{array}$ & $\begin{array}{l}\text { It is suitable for seismic events that do not induce the soft sediment } \\
\text { deformation structures in the profile and only can verify the earthquake } \\
\text { magnitude estimated by soft sediment deformation structure }\end{array}$ & $\begin{array}{l}\text { It is necessary to determine whether the rapidly } \\
\text { deposited sand layer is caused by earthquake, and } \\
\text { have a large error. }\end{array}$ \\
\hline
\end{tabular}

Earthquake magnitudes inferred from Lake Lisan and Luobozhai soft-sediment deformation structures.

\begin{tabular}{|c|c|c|c|c|c|c|c|c|c|c|c|c|}
\hline \multirow[t]{2}{*}{$\begin{array}{l}\text { Study } \\
\text { location }\end{array}$} & \multirow[t]{2}{*}{ Types } & \multirow{2}{*}{$\begin{array}{l}\text { Historical } \\
\text { liquefaction } \\
\text { method }\end{array}$} & \multicolumn{2}{|c|}{$\begin{array}{l}\text { Maximum } \\
\text { liquefied } \\
\text { distance }\end{array}$} & \multicolumn{2}{|c|}{$\begin{array}{l}\text { Thickness of } \\
\text { disturbed layer }\end{array}$} & \multicolumn{2}{|c|}{ Empirical formula } & \multirow{2}{*}{$\begin{array}{l}\text { Deformation } \\
\text { types } \\
\text { M }\end{array}$} & \multicolumn{2}{|c|}{$\begin{array}{l}\text { Thickness of } \\
\text { rapidly-deposited } \\
\text { sand layer }\end{array}$} & \multirow[t]{2}{*}{$M$} \\
\hline & & & $\begin{array}{l}\text { Distance } \\
(\mathrm{km})\end{array}$ & $M$ & $\begin{array}{l}\text { Thickness } \\
\text { (cm) }\end{array}$ & Shaking & $\begin{array}{l}\text { Thickness } \\
\text { (cm) }\end{array}$ & $M$ & & $\begin{array}{l}\text { Thickness } \\
\text { (cm) }\end{array}$ & $M$ & \\
\hline $\begin{array}{l}\text { Lake } \\
\text { Lisan }\end{array}$ & $\begin{array}{l}\text { Seismics- } \\
\text { related } \\
\text { deposit } \\
\text { (liquefied } \\
\text { layer and } \\
\text { dsirupted } \\
\text { layer) }\end{array}$ & $>5$ & $5-10$ & $\begin{array}{l}5.2- \\
6.8\end{array}$ & 13 & 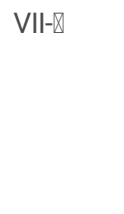 & 9 & 6.83 & $5.5-6.5$ & 2 & $\begin{array}{l}4.2- \\
6.6\end{array}$ & $\begin{array}{l}5.5- \\
6.5\end{array}$ \\
\hline Luobozhai & $\begin{array}{l}\text { liquefied } \\
\text { diapir }\end{array}$ & $>5$ & $5-10$ & $\begin{array}{l}5.2- \\
6.8\end{array}$ & 10 & $\bigotimes-\bigotimes$ & & & $6.5-8.0$ & 5 & $\begin{array}{l}5.2- \\
7.6\end{array}$ & $6-7$ \\
\hline
\end{tabular}

\section{Luobozhai lacustrine section}

The upper reaches of the Minjiang River are located in the north-central part of the "South-North Seismic Belt of China", which is affected by the Minjiang, Huya, Songpinggou, and Longmenshan faults, and characterized by frequent earthquakes (Fig. 9b). In recent years, four earthquakes with Ms $\geq 7$ have occurred in east Tibet (Wenchuan 2008, Yushu 2013, Lushan 2013 and Jiuzhaigou 2017), evidencing that the area is ongoing a strong active tectonics. Due to the region's alpine valley geomorphology and lack of Quaternary deposits, it is difficult to conduct paleoearthquake research by excavating trenches. The region contains many lakes dammed by paleoearthquake-induced landslides (Wang et al., 2005). Researchers have ascribed various SSD structures and environmental indexes (such as grain size and magnetic susceptibility) in the lacustrine sediments to multiple seismic events (e.g., Wang et al., 2011; Jiang et al., 2014, 2016; Xu et al., 2015; Zhong et al., 2019).

We recognized liquefied diapir in the Luobozhai Late-Quaternary lacustrine section, at Maoxian in the upper reaches of the Minjiang River, which is overlain and underlain by undeformed beds (Fig. 9b). Criteria for correlating SSDS with seismic events have been widely discussed (e.g. Sims, 1975; Bowman et al., 2004; Owen and Moretti, 2011; Jiang et al., 2016), with the following considerations. (1) Most researchers emphasize the location of the SSDS in a seismically active region. Since 1933, at least five earthquakes with $M>7$ have occurred along the nearby Minjiang River fault, at Diexi (1933), Songpan (1976), northern Pingwu (1976), Wenchuan (2008) and Jiuzhaigou (2017). (2) The Luobozhai section is located close to the Minjiang Fault and is only 10 km from the Songpinggou Fault. Tectonic activity along these faults during the late Quaternary has been confirmed by many studies (e.g. Chen et al., 1994; An et al., 2008; Zhang et al., 2016; Zhong, 2017, Ren et al., 2018). (3) The widely distributed lacustrine sediments mostly comprise liquefaction-prone deposits, such as silt and fine sand, with grain sizes concentrated in the range of 20-200 $\mu \mathrm{m}$ : for example, the nearby (about $10 \mathrm{~km}$ ) Xinmocun (Jiang et al., 2014) and Shawan sections (Zhong, 2017), which have great potential for liquefaction and fluidization (Lee et al., 2003). (4) The SSDS in the study area can be traced laterally for $30 \mathrm{~km}$ along the Minjiang River, and are repeated vertically (Wang et al., 2011; Jiang et al., 2014; Zhong et al., 2019). (5) The liquefied diapir are separated by undeformed beds, and only contains centimeter-scale deformation structures (Fig. 9b). (6) The liquefied diapir in the Luobozhai section is comparable with those produced experimentally (Anketell et al., 1970; Alfaro et al., 1997) and with those described in studies of paleoearthquakes (Jiang et al., 2014; Zhong et al., 2019). (7) The deformation structures in flood retention deposits have parallel sandy layers, a distinct change in grain size, and a deformation magnitude that decreases downwards in the vertical section (Rana et al., 2016); typical morphologies are simple

Page $8 / 21$ 
folds to complex contortions. However, if the disturbance were due to fluvial processes, then it is likely that the deformation caused by liquefaction and fluidization would have taken place just only near the sedimentary surface (Kundu et al., 2011). Structures typical of rapid pore-water movements (Li et al., 1996), slope failure (Alsop and Marco, 2011), channel erosion (Dasgupta, 1998) and permafrost (Vandenberghe, 1992) were not observed. The liquefied diapir were likely triggered by seismic activity, although overloading (Moretti and Sabato, 2007) and rapid sedimentation (Lowe, 1975) cannot be discounted. Therefore, the liquefied diapir in the Luobozhai lacustrine section are attributed to seismic activity, and were not influenced by flash floods, fluvial processes or other processes. Considering that the liquefied diapir in Luobozhai section are strongly deformed, and that the deformed layer contains a notable clay content that will result in a relatively high viscosity, a relatively large magnitude would be required to cause its liquefaction related deformation (Tian et al., 2016; Su and Qiao, 2018). By using the six methods described above to determine the earthquake magnitudes, we suggest that the liquefied diapir in the Luobozhai section may represent earthquake activity with magnitudes 6-7 (Table 2).

\section{Liquefaction hazard}

Sand or soil liquefaction and liquefaction-induced lateral spreading are the most pervasive types of seismic damage to structures and critical facilities infrastructures (e.g. buildings, roads, bridges etc.) (Obermeier, 2005; Chen et al., 2013; Liu et al., 2016; Das et al., 2018; Naik et al., 2019). Such damages have been observed in almost all recent major earthquakes, including the 1999 Chi-chi (Taiwan) earthquake (Chang et al., 2012 ), the 2008 Wenchuan (China) earthquake (Liu-Zeng et al., 2012), the 2010 Maule (Chile) earthquake (Yasuda et al., 2010), the 2011 Christchurch (New Zealand) earthquake (Robinson et al., 2014), the 2011 Tohoku (Japan) earthquake (Sasaki et al., 2012), the 2012 Emilia (Italy) earthquake (Papathanassiou et al., 2015), and the 2018 Palu (Indonesia) earthquake (Song et al., 2019). Current methods of predicting the liquefaction potential were largely developed using data from relatively young deposits or deposits that have been frequently disturbed (i.e., in areas of high seismicity) (Saftner et al., 2015). However, it is difficult to assess the liquefaction potential in older deposits. Liquefaction and fluidization, as well as SSDS, are common phenomena associated with seismic ground shaking, and have been reported from modern to Paleozoic times (Mazumder et al., 2006; van Loon, 2009; Qiao et al., 2017) in all sedimentary environments (Moretti et al., 1999). In many places, the SSDS record can be interpreted far enough back in time to yield sufficient data (e.g., paleoseismic activity and earthquake magnitude) for hazard assessment, thereby providing a sound basis for the engineering and design of critical structures such as hospitals, bridges, and nuclear facilities (Obermeier et al., 2005). Therefore, the use of SSDS constitutes an effective and inexpensive approach to recognize zones of different liquefaction hazard, making it readily applicable in addressing (1) whether there has been strong Holocene or late Pleistocene shaking in the region (Obermeier et al., 1985); (2) where the tectonic sources (e.g. paleo-earthquake epicentre) were located (Rodríguez-Pascua et al., 2010); and (3) what was the strength of the shaking (Zhong et al., 2017). Therefore, the SSDS have a lower formation threshold, higher preservational potential and longer time than geomorphic markers formed by surface ruptures. Thus, future combined studies of SSDS and Quaternary surface faults are required to provide reliable paleoseismological information in tectonically active regions.

\section{Discussion}

The types of SSDS and the maximum liquefaction distance together yield a more reliable method to determine the seismic shaking than the six methods described above, and their usefulness is demonstrated by the two case studies. However, the following five points should be considered when we determine the magnitude of an earthquake using SSDS. (1) Due to the complex deformation mechanism and triggering factors of the SSDS, we must firstly determine the origin and trigger mechanism of the SSDS (Sims, 1975; Mills, 1983; Jones and Omoto, 2000; Owen and Moretti, 2011; Zhong et al., 2020b). (2) The morphology of the SSDS and the thickness of seismites are controlled by the properties (e.g. sedimentary environment, lithology, physical characteristics of the sediment, liquefaction and/or fluidization factors) of the SSDS (Hurst et al., 2011). These factors could lead to incorrect determination of the type of SSDS (e.g. flame vs diapir); therefore, careful consideration needs to be paid when analysing the SSDS characteristics (type, deformation strength, disturbed thickness etc.). (3) Uncertainty of the paleoearthquake location and the spatial distribution of the paleoliquefaction point must be considered. To minimize uncertainty, we use the horizontal distance between the liquefaction deformation record (or the location of the liquefied deformation section) and the seismogenic fault or epicenter. (4) In order to verify the method's reliability, the reconstructed seismic shaking should be comparable with the magnitudes obtained by the modern earthquakes, paleoearthquakes in the study area. (5) Earthquakes with M $>5$ may not cause SSDS or may not be recorded in the sedimentary succession (Moretti et al., 1999), and a single seismic shock can induce superimposed deformed beds (Gibert et al., 2011). This can lead to the omission or enhancement of seismic events.

Hence, when studying paleo-earthquakes on the basis of SSDS, the sedimentology and micro-indices (e.g. grain size, magnetic susceptibility etc.) are necessary to identify those seismic events that did not cause SSDS but may have induced large amounts of debris (e.g. landslides, dust etc.). This can help us to obtain long sequences of seismic events. However, the source and chemical properties of the lacustrine sediments are affected by the strongearthquake-induced debris, and may also be affected by extreme weather (e.g. sand storms, Chen et al., 2013), rapid weathering (Liang and Jiang, 2017) and human activities (Karlin and Abella, 1996). Therefore, quantifying seismic events in lacustrine sediments requires a combination of macroscopic SSDS and micro-environmental indicators, as well as sedimentary evidence. Similarly, for lacustrine sediments, it is best to use a combination of an underlying SSDS layer and an overlying sand layer, in addition to the six methods described here, to obtain accurate magnitudes of paleo-earthquakes.

\section{Conclusions}

Six methods developed to infer the magnitude of past earthquakes were applied to a succession of the Lisan Formation, and yielded earthquake

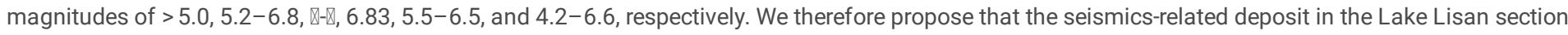
most likely represents earthquakes with magnitudes of 5.5-6.5, thus confirming previous estimates of magnitudes ( $M \geq 5.5)$. Application of these same methods to the liquefied diapir in late-Quaternary lacustrine sediments in the upper reaches of the Minjiang River at Luobozhai indicates that the liquefied 
diapir are associated with earthquake magnitudes of 6-7. This estimate agrees well with the results of previous studies. Our work provides a means of gaining a better understanding of the regional seismic hazard at sites where it is difficult to conduct paleoearthquake research by excavating trenches, for example due to rough topography, strong erosion or the absence of co-seismic ruptures, especially the paleoearthquakes recorded by lacustrine sediments. The combination of the six methods can provide a relatively convenient and novel method for determining seismic shaking. This study also can serves as a reference for comparing methods of calculating the magnitude of a paleoearthquake based on the surface rupture parameters. This new, integrated method provides reliable and comparable information on the seismic shaking, suggesting that a similar approach could be successfully applied to quantify the magnitude of an earthquake on the Tibetan Plateau or elsewhere. It also provides a novel method for us to research the long-term seismic activity and risk in tectonically active regions.

\section{Declarations}

\section{Acknowledgements}

We thank Xiufu Qiao, Bizhu He and Zengzhao Feng for helpful discussions that improved the manuscript.

\section{Disclosure statement}

No potential conflict of interest was reported by the authors.

\section{Funding}

This research was financially supported by the National Natural Science Foundation of China $(41807298,41702372,41572346)$, the China Postdoctoral Science Foundation (2019M650788), the Special Project of Fundamental Scientific Research of the Institute of Geology, China Earthquake Administration (IGCEA1713), and the China Geological Survey (DD20190319هDD20190059).

\section{References}

1. Agnon, A., Migowski, C., Marco, S (2006). Intraclast breccias in laminated sequences reviewed: Recorders of paleo-earthquakes, Special Papers Geological Society of America. 401, 195-214.

2. Alfaro, P., Moretti, M., Soria, J. M. (1997). Soft sediment deformation structures induced by earthquakes (seismites) in Pliocene lacustrine deposits (Guadix-Baza Basin, Central Betic Cordillera), Eclogae Geologicae Helvetiae. 90, 531-540.

3. Alfaro, P., Delgado, J., Estévez, A., Molina, J., Moretti, M., Soria, J (2002). Liquefaction and fluidization structures in Messinian storm deposits (Bajo Segura Basin, Betic Cordillera, (southern Spain), International Journal of Earth Sciences. 91(3): 505-513.

4. Allen, J. R. L. (1986). Earthquake magnitude-frequency, epicentral distance, and soft-sediment deformation in sedimentary basins, Sedimentary Geology. 46, 67-75.

5. Alsop, G. I., Marco, S (2011). Soft-sediment deformation within seismogenic slumps of the Dead Sea basin, Journal of Structural Geology. 33(4): 433457.

6. Ambraseys, N. N. (1988). Engineering seismology: part I, Earthquake engineering \& structural dynamics. 17, 1-50.

7. Ambraseys, N. N., Finkel, C. F. (1991). Long-term seismicity of Istanbul and of the Marmara Sea region, Terra Nova. 3(5): 527-539.

8. Ambraseys, N. (2002). The seismic activity of the Marmara Sea region over the last 2000 years, Bulletin of the Seismological Society of America. 92(1): 1-18.

9. Ambraseys, N. (2009). Earthquakes in the Mediterranean and Middle East: a multidisciplinary study of seismicity up to 1900, Cambridge University Press. Cambridge.

10. An, W. P., Zhao, J. Q., Yan, X. B., Li, Z. H., Su, Z. H. (2008). Tectonic deformation of lacustrine in Qiangyang on the Minjiang fault zone and ancient earthquake, Seismology and Geology. 30(4): 980-988 (in Chinese with English abstract).

11. Anketell, J. M., Cegla, J., Dzulinsky, S (1970). On the deformational structures in systems with reversed density gradients, Annales de la Société Géologique de Pologne. 40(1): 3-30.

12. Archer, C., Noble, P., Rosen, M. R., Sagnotti, L., Florindo, F., Mensing, S., Piovesan, S., Michetti, G., Michetti, A. M. (2019). Lakes as paleoseismic records in a seismically-active, low-relief area (Rieti Basin, central Italy), Quaternary Science Reviews. 211, 186-207.

13. Audemard, F. A. De., Santis, F (1991). Survey of liquefaction structures induced by recent moderate earthquakes, Bulletin of Engineering Geology \& the Environment. 44, 5-16.

14. Avşar, U., Hubert-Ferrari, A, De., Batist, M., Lepoint, G., Schmidt, S., Fagel, N (2014). Seismically-triggered organic-rich layers in recent sediments from Göllüköy Lake (North Anatolian Fault, Turkey), Quaternary Science Reviews. 103, 67-80.

15. Avşar, U., Hubert-Ferrari, A. De., Batist, M., Schmidt, S., Fagel, N (2015). Sedimentary records past earthquakes in Boraboy Lake during the last ca 600 years (North Anatolian Fault, Turkey), Palaeogeography, Palaeoclimatology, Palaeoecology. 433, 1-9.

16. Beck, C. (2009). Late Quaternary lacustrine paleo-seismic archives in north-western Alps: Examples of earthquake-origin assessment of sedimentary disturbances, Earth-Science Reviews. 96(4): 327-344. 
17. Berra, F., Felletti, F (2011). Syndepositional tectonics recorded by soft-sediment deformation and liquefaction structures(continental Lower Permian sediments, Southern Alps, Northern Italy)『stratigraphic significance, Sedimentary Geology. 235(3-4): 249-263.

18. Bommer, J. J., Rodríguez, C. E. (2002). Earthquake-induced landslides in Central America, Engineering Geology. 63(3-4): 189-220.

19. Bowman, D., Korjenkov, A., Porat, N (2004). Late-Pleistocene seismites from Lake Issyk-Kul, the Tien Shan range, Kyrghyzstan, Sedimentary Geology. $163,211-228$.

20. Cao, Z. Z., Yuan, X. N., Wang, W. N., Sun, R (2010). Distribution and characteristics of gravelly soils liquefaction in the Wenchuan Ms 8.0 Earthquake, China Civil Engineering Journal. (s2): 312-319.

21. Chang, M., Kuo, C. P., Hsu, R. E., Shau, S. H., Lin, T. M. (2012). Liquefaction potential and post-liquefaction settlement evaluations of the Chuoshui river alluvial fan in Taiwan, Bulletin of Engineering Geology and the Environment. 71(2): 325-336.

22. Chen, F., Qiang, M., Zhou, A., Xiao, S., Chen, J., Sun, D (2013). A 2000-year dust storm record from Lake Sugan in the dust source area of arid China, Journal of Geophysical Research: Atmospheres. 118(5): 2149-2160.

23. Chen, L. W., Yuan, X, M., Sun, R (2013). Review of liquefaction phenomena and geotechnical damage in the 2011 New Zealand Mw 6. 3 earthquake, World Earthquake Engineering. 29(3): 1-9 (in Chinese with in English abstract).

24. Chen, L., Wang, H., Ran, Y. K., Lei, S. Li, X (2014). The 2013 Lushan Ms 7.0 earthquake: varied seismogenic structure from the 2008 Wenchuan earthquake, Seismological Research Letters. 85(1): 34-39.

25. Chen, S. F., Wilson, C. J. L., Deng, Q. D., Zhao, X. L., Zhi, L. L. (1994). Active faulting and block movement associated with large earthquakes in the Min Shan and Longmen Mountains, northeastern Tibetan Plateau, Journal of Geophysical Research: Solid Earth. 99, 24025-24038.

26. Das, S., Ghosh, S., Kayal, J. R. (2019). Liquefaction potential of Agartala City in Northeast India using a GIS platform, Bulletin of Engineering Geology and the Environment. 78(4):2919-2931.

27. Dasgupta, P. (1998). Recumbent flame structures in the Lower Gondwana rocks of the Jharia Basin, India-a plausible origin, Sedimentary Geology. 119(119): 253-261.

28. Davenport, C. A., Ringrose, P. S. (1987). Deformation of Scottish Quaternary sediment sequence by strong earthquake motions, in Jones, M. E., and Preston, R. M., eds., Deformation of sediments and sedimentary rocks, London, Geological Society Special Publications. Pp. $299-314$.

29. Davis, R. O., Berrill, J. B. (1983). Comparison of a liquefaction theory with field observations, Geotechnique. 34(4): 627-629.

30. Fairless, G. J., Berrill, J. B. (1984). Liquefaction during historic earthquakes in New Zealand, Earthquake Engineering. 17, $280-291$.

31. Fan, X., Westen, C. J., Korup, O., Gorum, T., Xu, Q., Dai, F., Huang, R., Wang, G (2012). Transient water and sediment storage of the decaying landslide dams induced by the 2008 Wenchuan earthquake, China Geomorphology. 171, 58-68.

32. Fan, J., Jiang, H., Shi, W., Guo, Q., Zhang, S., Wei, X., ... \& Xiao, J. (2020). A 450-year lacustrine record of recurrent seismic activities around the Fuyun fault, Altay Mountains, northwest China. Quaternary International $₫ 558: 75-88$.

33. Fu, Z. X. (1997). Mechanic study on seismicity of the Chinese mainland. Seismological Press, Beijing, Pp.44-45 (in Chinese).

34. Galli, P., Meloni, F (1993). .Liquefazione Storica, Uncatalogo nazionale, Quat Ital. J. Quat, Sci. 6, 271-292.

35. Galli, P., Ferreli, L (1995). Methodological approach for historical liquefaction researches, In Serva, L., Slemmons, D.B. (Eds.), Perspectives in Paleoseismology. Association of Engineering Geologists, Spec. Publ. 6, Sudbury, MA, pp. 35-48.

36. Galli, P. (1999). Active tectonicsa longthe Wadi Araba-Jordan Valley transform fault, journal of geophysical research, vol. 104, no. b2, pages 2777-2796, February $10,1999$.

37. Galli, P. (2000). New empirical relationships between magnitude and distance for liquefaction, Tectonophysics. 324(3): 169-187.

38. Gibert, L., Alfaro, P., García-Tortosa, F. J., Scott, G (2011). Superposed deformed beds produced by single earthquakes (Tecopa Basin, California): insights into paleoseismology, Sedimentary Geology. 235 (3-4): 148-159.

39. Guiraud, M., Plaziat, J. C. (1993). Seismites in the fluviatile bima sandstones: identification of paleoseisms and discussion of their magnitudes in a cretaceous synsedimentary strike-slip basin (upper benue, nigeria), Tectonophysics. 225(4): 0-522.

40. Harrison, P., Maltman, A. J. (2003). Numerical modelling of reverse-density structures in soft non-newtonian sediments, Geological Society London Special Publications. 216(1): 35-50.

41. Hempton, M. R., Dewey, J. F. (1983). Earthquake-induced deformation structures in young lacustrine sediments, East Anatolian Fault, southeast Turkey, Tectonophysics. 98:7-14.

42. Hibsch, C., Alvarado, A., Yepes, H., Perez, V. H., Sébrier, M (1997). Holocene liquefaction and soft-sediment deformation in Quito (Ecuador): a paleoseismic history recorded in lacustrine sediments, Journal of Geodynamics. 24, 259-280.

43. Howarth, J. D., Fitzsimons, S. J., Norris, R. J., Jacobsen, G. E. (2012). Lake sediments record cycles of sediment flux driven by large earthquakes on the Alpine fault, New Zealand, Geology. 40(12): 1091-1094.

44. Hurst, A., Scott, A., Vigorito, M (2011). Physical characteristics of sand injectites, Earth Science Reviews. 106(3-4):215-246.

45. Jiang, H. C., Mao, X., Xu, H. Y., Yang, H. L., Ma, X. L., Zhong, N. Li, Y. H. (2014). Provenance and earthquake signature of the last deglacial Xinmocun lacustrine sediments at Diexi, east Tibet, Geomorphology, 204, 518-531.

46. Jiang, H., Zhong, N., Li, Y., Xu, H., Yang, H., Peng, X (2016). Soft sediment deformation structures in the Lixian lacustrine sediments, eastern Tibetan Plateau and implications for postglacial seismic activity, Sedimentary Geology. 344, 123-134. 
47. Jiang, H., Zhong, N., Li, Y., Ma, X., Xu, H., Shi, W., Zhang, S., Nie, G (2017). A continuous 13.3-ka record of seismogenic dust events in lacustrine sediments in the eastern Tibetan Plateau, Scientific Reports. 15686 (7): 1-9.

48. Jones, A. P., Omoto, K (2000). Towards establishing criteria for identifying trigger mechanisms for soft-sediment deformation: a case study of late Pleistocene lacustrine sand and clays, Onikobe and Nakayamadaira Basins, northeastern Japan, Sedimentology. 47:1211-1226.

49. Karlin, R. E., Abella, S. E. B. (1996). A history of Pacific Northwest earthquakes recorded in Holocene sediments from Lake Washington, Journal of Geophysical Research: Solid Earth. 101(B3): 6137-6150.

50. Katz, A., Agnon, A., Marco, S (2009). Earthquake-induced barium anomalies in the lisan formation, dead sea rift valley, Israel, Earth and Planetary Science Letters. 286(1-2): 219-229.

51. Keefer, D. K. (1984). Landslides caused by earthquakes, Geological Society of America Bulletin. 95(4): 406-421.

52. Klinger, Y., Rivera, L., Haessler, H., Maurin, J. C. (1999). Active faulting in the Gulf of Aqaba: new knowledge from the Mw 7.3 earthquake of 22 November 1995, Bulletin of the Seismological Society of America. 89(4): 1025-1036.

53. Kundu, A., Goswami, B., Eriksson, P. G., Chakraborty, A (2011). Palaeoseismicity in relation to basin tectonics as revealed from soft-sediment deformation structures of the Lower Triassic Panchet formation, Raniganj basin (Damodar valley), eastern India, Journal of Earth System Science. 120, 167-181.

54. Kuribayashi, E., Tatsuoka, F (1975). Brief review of liquefaction during earthquakes in Japan, Soils and Foundations. 15(4): 81-92.

55. Lay, T., Kanamori, H., Ammon, C. J., Nettles, M., Ward, S. N., Aster, R. C., Beck ,S. L., Bilek, S. L., Brudzinski, M. R., Butler, R., Deshon, H. R., Ekstrom, G., Satake, K., DeShon, H. R. (2005). The great Sumatra-Andaman earthquake of 26 december 2004, Science. 308(5725): 1127-1133.

56. Lee, D. H., Ku, C., Yuan, H (2004). A study of the liquefaction risk potential at Yuanlin, Taiwan, Engineering Geology. 71(1): 97-117.

57. Li, L. Z., Sun, Y. Q., Li, Y. D. (1991). Seismic wave in sedimentary layers and earthquake magnitude, Earthquake. (2): 64-72(in Chinese with English abstract).

58. Li, T., Chen, J., Fang, L., Chen, Z., Thompson, J. A., Jia, C (2016). The 2015 Mw 6.4 Pishan earthquake: seismic hazards of an active blind wedge thrust system at the western Kunlun range front, northwest Tibetan Plateau, Seismological Research Letters. 87(3): 601-608.

59. Li, Y., Craven, J., Schweig, E. S., Obermeier, S. F. (1996). Sand boils induced by the 1993 Mississippi River flood: could they one day be misinterpreted as earthquake induced liquefaction, Geology. 24, 171-174.

60. Liang, L., Jiang, H (2017). Geochemical composition of the last deglacial lacustrine sediments in East Tibet and implications for provenance, weathering, and earthquake events, Quaternary International. 430, 41-51.

61. Liang, L., Dai, F., Jiang, H., Zhong, N (2018). A preliminary study on the soft-sediment deformation structures in the Late Quaternary lacustrine sediments at Tashkorgan, northeastern Pamir, China. Acta Geologica Sinica (English Edition). 92(4): 1574-1591.

62. Liu, F., Li, Z., Jiang, M., Frattini, P., Crosta, G (2016). Quantitative liquefaction-induced lateral spread hazard mapping, Engineering Geology. $207,36-47$.

63. Liu, G., Wang, Q., Qiao, X. J., Yang, S. M., You, X. Z., Zhang, R., Zhao, B., Tan, K., Zhou, R., Fang, R. X. (2015) .The 25 April 2015 Nepal Ms 8.1 earthquake slip distribution from joint inversion of teleseismic, static and high-rate GPS data. Chinese Journal of Geophysics. 58(11): $4287-4297$ (in Chinese with English abstract).

64. Liu, Y., Xie, J. F. (1984). Vibration liquefaction of sandy soil. Beijing: Seismological Press, Pp.1-237 (in Chinese).

65. Liu, Z. J., Wang, P., Zhang, Z. H., Li, Z. G., Cao, Z. Z., Zhang, J. Y., Yuan, X. M., Wang, W., Xing, X. C. (2016). Liquefaction in western Sichuan Basin during the $2008 \mathrm{Mw} 7.9$ Wenchuan earthquake, China, Tectonophysics, 694, 214-238.

66. Lowe, D. R. (1975). Water escape structures in coarse grained sediments, Sedimentology. 22, 157-204.

67. Lu, Y., Waldmann, N., Ian Alsop, G., Marco, S (2017). Interpreting soft sediment deformation and mass transport deposits as seismites in the Dead Sea depocenter, Journal of Geophysical Research: Solid Earth. 122(10): 8305-8325.

68. Lu, Y. , Wetzler, N. , Waldmann, N. , Agnon, A. , \& Marco, S. .2020. A 220,000-year-long continuous large earthquake record on a slow-slipping plate boundary. Science Advances, 6(48), eaba4170.

69. Malamud, B. D., Turcotte, D. L., Guzzetti, F., Reichenbach, P (2004). Landslides, earthquakes, and erosion, Earth \& Planetary Science Letters. 229(1): 4559.

70. Marco, S., Agnon, A., Stein, M., Ron, H (1994). A 50,000 years continuous record of earthquakes and surface ruptures in the Lisan Formation, the Dead Sea Graben. United States Geological Survey Open-File Report, Pp. 112-114.

71. Marco, S., Agnon, A (1995). Prehistoric earthquake deformations near Masada, Dead Sea graben Geology. 23(8): 695-698.

72. Marco, S., Stein, M., Agnon, A., Ron, H (1996). Long term earthquake clustering: a 50,000 year paleoseismic record in the Dead Sea Graben, J. Geophys. Res. 101 (B3), 6179- 6192.

73. Marco, S., Agnon, A (2005). High-resolution stratigraphy reveals repeated earthquake faulting in the Masada fault zone, Dead Sea transform, Tectonophysics. 408(1):101-112.

74. Maurer, B. W., Green, R. A., Quigley, M. C., Bastin, S (2015). Development of magnitude-bound relations for paleoliquefaction analyses: New Zealand case study, Engineering Geology. 197, 253-266.

75. Mazumder, R., Van Loon, A. J., Arima, M (2006). Soft-sediment deformation structures in the Earth's oldest seismites, Sedimentary Geology. 186: $19-26$.

76. Mccalpin, J. P., Mccalpin, J. P., Nelson, A. R. (1996). Chapter 1 introduction to paleoseismology, International Geophysics. 62(09): 1-32. 
77. McHugh, C. M., Seeber, L., Cormier, M. H., Dutton, J., Cagatay, N., Polonia, A., Gorur, N (2006). Submarine earthquake geology along the north Anatolia fault in the Marmara Sea, Turkey, a model for transform basin sedimentation, Earth and Planetary Science Letters. 248(3): 661-684.

78. Migowski, C., Agnon, A., Bookman, R., Negendank, J. F. W., Stein, M (2004). Recurrence pattern of Holocene earthquakes along the Dead Sea transform revealed by varve-counting and radiocarbon dating of lacustrine sediments, Earth and Planetary Science Letters. 222(1): $301-314$.

79. Mills, P. C. (1983). Genesis and diagnostic value of soft-sediment deformation structures-a review, Sediment Geology. 35:83-104.

80. Moernaut, J., Daele, M. V., Heirman, K., Fontijn, K., Strasser, M., Pino, M., Roberto, U., De Batist, M (2014). Lacustrine turbidites as a tool for quantitative earthquake reconstruction: new evidence for a variable rupture mode in south central Chile, Journal of Geophysical Research: Solid Earth. 119(3): 16071633.

81. Molenaar, A. , Daele, M. V. , Vandorpe, T. , Degenhart, G. , MD Batist, \& Urrutia, R. , et al. What controls the remobilization and deformation of surficial sediment by seismic shaking? linking lacustrine slope stratigraphy to great earthquakes in south-central chile. Sedimentology. doi: $10.1111 /$ sed.12856

82. Molina, J. M., Alfaro, P., Moretti, M., and Soria, J. M. (1998). Soft-sediment deformation structures induced by cyclic stress of storm waves in tempestites (Miocene, Guadalquivir basin, Spain), Terra Nova. 10, 145-150.

83. Monecke, K., Anselmetti, F. S., Becker, A., Sturm, M., Giardini, D (2004). The record of historic earthquakes in lake sediments of central Switzerland, Tectonophysics. 394, 21-40.

84. Monecke, K., Anselmetti, F. S., Becker, A., Schnellmann, M., Sturm, M., Giardini, D (2006). Earthquake-induced deformation structures in lake deposits: A Late Pleistocene to Holocene paleoseismic record for Central Switzerland, Eclogae Geologicae Helvetiae. 99(3): $343-362$.

85. Moretti, M., Alfaro, P., Caselles, O., Canas, J. A. (1999). Modelling seismites with a digital shaking table, Tectonophysics. 304, $369-383$.

86. Moretti, M., Sabato, L (2007). Recognition of trigger mechanisms for soft-sediment deformation in the Pleistocene lacustrine deposits of the Sant $₫$ Arcangelo Basin (Southern Italy): Seismic shock vs, overloading. Sedimentary Geology. 196(1-4): 31-45.

87. Moretti, M., Alfaro, P., Owen, G (2016). The environmental significance of soft-sediment deformation structures: key signatures for sedimentary and tectonic processes, Sedimentary Geology. 344, 1-4.

88. Mugnier, J. L., Huyghe, P., Gajurel, A. P., Upreti, B. N., Jouanne, F (2011). Seismites in the Kathmandu basin and seismic hazard in central Himalaya. Tectonophysics. 509(1): 33-49.

89. Naik, S. P., Mohanty, A., Porfido, S., Tuttle, M., Gwon, O., Kim, Y. S. (2019). Intensity estimation for the 2001 Bhuj earthquake, India on ESI-07 scale and comparison with historical 16th June 1819 Allah Bund earthquake: a test of ESI-07 application for intraplate earthquakes, Quaternary International (Aceepted). doi.org/10.1016/j.quaint.2019.12.024.

90. Neuwerth, R., Suter, F., Guzman, C. A., Gorin, G. E. (2006). Soft-sediment deformation in a tectonically active area: The Plio-Pleistocene Zarzal Formation in the Cauca valley (western Colombia), Sedimentary Geology. 186, 67-88.

91. Obermeier, S. F., Gohn, G. S., Weems, R. E., Gelinas, R. L., Rubin, M (1985). Geologic evidence for recurrent moderate to large earthquakes near Charleston, South Carolina, Science, 277:408-410.

92. Obermeier, S. F. (1998). Liquefaction evidence for strong earthquakes of Holocene and latest Pleistocene ages in the states of Indiana and Illinois, USA, Engineering Geology. 50(3): 227-254.

93. Obermeier, S. F. (1996). Use of liquefaction-induced features for paleoseismic analysis-an overview of how seismic liquefaction features can be distinguished from other features and how their regional distribution and properties of source sediment can be used to infer the location and strength of Holocene paleo-earthquakes, Engineering Geology. 44(1-4): 1-76.

94. Obermeier, S. F., Pond, E. C., Olson, S. M. (2002). Paleoliquefaction studies in continental settings: geologic and geotechnical factors in interpretations and back-analysis, US Geological Survey Open-File Report. 1-29.

95. Obermeier, S. F., Olson, S. M., Green, R. A. (2005). Field occurrences of liquefaction-induced features: a primer for engineering geologic analysis of paleoseismic shaking, Engineering Geology. 76(3-4): 209-234.

96. Owen, G (1987). Deformation processes in unconsolidated sands, Geological Society, London, Special Publications. 29(1), 11-24.

97. Owen, G., Moretti, M (2008). Determining the origin of soft-sediment deformation structures: a case study from Upper Carboniferous delta deposits in south-west Wales, UK, Terra Nova. 20(3): 237-245.

98. Owen, G., Moretti, M (2011). Identifying triggers for liquefaction-induced soft-sediment deformation in sands, Sedimentary Geology. 235(3):141-147.

99. Papadopoulos, G. A., Lefkopoulos, G (1993). Magnitude-Distance relation for liquefaction in soil from earthquakes, Bulletin of the Seismological Society of America. 83, 925-938.

100. Papathanassiou, G., Mantovani, A., Tarabusi, G., Rapti, D., Caputo, R (2015). Assessment of liquefaction potential for two liquefaction prone areas considering the May 20, 2012 Emilia (Italy) earthquake, Engineering Geology. 189, 1-16.

101. Postma, G. (1983). Water escape structures in the context of a depositional model of a mass flow dominated conglomeratic fan-delta (Abrioja Formation, Pliocene, Almeria Basin, SE Spain), Sedimentology. 30, 91-103.

102. Qiao, X. F., Li, H. B. (2008). Pillow, ball-and-pillow structures $₫$ paleo-seismic records within strata, Geological Review 54(6): 721-730 (in Chinese with English abstract).

103. Qiao, X., Guo, X (2013). Early Jurassic soft-sediment deformation interpreted as seismites in the Wuqia pull-apart basin and the strike-slip TalasFerghana fault, Xinjiang, China, Acta Geologica Sinica (English Edition). 87(3): 730-737.

104. Qiao, X. F., Li, H. B., Su, D. C., He, B. Z., Tian, H. S., Guo, X. P., Song, T. R., Lu, H. B., Gao, L. Z., He, J., Yuan, X. Q., Zhou, W., Zhang, M., Sun, A. P., Wang, A. D. (2017). Soft-sediment deformation structures-earthquakes and seismic records. Beijing: Geological Publishing House, pp.1-264 (in Chinese).

Page 13/21 
105. Ran, Y. K., Deng, Q. D. (1999). History, status and trend about the research of paleoseismology, Chinese Science Bulletin. 44(10):880-889 (in Chinese with English abstract).

106. Rana, N., Bhattacharya, F., Basavaiah, N., Pant, R. K., Juyal, N (2013). Soft sediment deformation structures and their implications for Late Quaternary seismicity on the south Tibetan detachment system, central Himalaya (Uttarakhand), India, Tectonophysics. 592, $165-174$.

107. Rana, N., Sati, S. P., Sundriyal, Y., Juyal, N (2016). Genesis and implication of soft-sediment deformation structures in high-energy fluvial deposits of the Alaknanda Valley, Garhwal Himalaya, India, Sedimentary Geology. 344, 263-276.

108. Ren, J., Xu, X., Zhang, S., Yeats, R. S., Chen, J., Zhu, A., Liu, S (2018). Surface rupture of the 1933 M 7.5 Diexi earthquake in eastern Tibet: implications for seismogenic tectonics, Geophysical Journal International. 212(3): 1627-1644.

109. Robinson, K., Cubrinovski, M., Bradley, B. A. (2014). Lateral spreading displacements from the 2010 Darfield and 2011 Christchurch earthquakes, International Journal of Geotechnical Engineering. 8(4): 441-448.

110. Rodríguez, C. E., Bommer, J. J., Chandler, R. J. (1999). Earthquake-induced landslides: 1980-1997, Soil Dynamics and Earthquake Engineering. 18(5): 325-346.

111. Rodríguez-Pascua, M. A., Calvo, J. P., De Vicente, G., Gómez-Gras, D (2000). Soft-sediment deformation structures interpreted as seismites in lacustrine sediments of the Prebetic Zone, SE Spain, and their potential use as indicators of earthquake magnitudes during the Late Miocene, Sedimentary Geology. 135(1): 117-135.

112. Rodríguez-Pascua, De., Vicente, G., Calvo, J. P., Pérez-López, R (2003). Similarities between recent seismic activity and paleoseismites during the Late Miocene in the external Betic Chain (Spain)『relationship by 'b' value and the fractal dimension, Journal of Structural Geology. 25(5): 749-763.

113. Rodríguez-Pascua, M. A., Garduño-Monroy, V. H., Israde-Alcántara, I., Pérez-López, R (2010). Estimation of the paleoepicentral area from the spatial gradient of deformation in lacustrine seismites (Tierras Blancas Basin, Mexico), Quaternary International. 219(1-2): 66-78.

114. Saftner, D. A., Green, R. A., Hryciw, R. D. (2015). Use of explosives to investigate liquefaction resistance of aged sand deposits, Engineering Geology. $199,140-147$

115. Salomon, M. L., Grasemann, B., Plan, L., Gier, S., Martin, P. J., Schöpfer, (2018). Seismically-triggered soft-sediment deformation structures close to a major strike-slip fault system in the eastern Alps (Hirlatz cave, Austria), Journal of Structural Geology. 110, 102-115.

116. Sasaki, Y., Towhata, I., Miyamoto, K., Shirato, M., Narita, A., Sasaki, T., Sako, S (2012). Reconnaissance report on damage in and around river levees caused by the 2011 off the Pacific coast of Tohoku earthquake, Soils Found. 52, 1016-1032.

117. Schwab, M. J., Werner, P., Dulski, P., McGee, E., Nowaczyk, N. R., Bertrand, S., Leroy, S. A. (2009). Palaeolimnology of Lake Sapanca and identification of historic earthquake signals, northern Anatolian fault zone (Turkey), Quaternary Science Reviews. 28(11): 991-1005.

118. Scott, B., Price, S (1988). Earthquake-induced structures in young sediments, Tectonophysics. 147, 165-170.

119. Seed, H. B., Idriss, I. M. (1971). Simplified procedure for evaluating soil liquefaction potential, Journal of Soil Mechanics \& Foundations Div. 97, 12491273.

120. Seilacher, A. (1969). Fault-graded beds interpreted as seismites, Sedimentology. 13, 155-159.

121. Shanmugam, G. (2016). The seismite problem, Journal of Palaeogeography. 5(4):318-362.

122. Shapira, A., Avni, R., Nur, A (1993). A new estimate for the epicenter of the Jericho earthquake of 11 July 1927, Israel Journal of Earth Sciences. 42(2): 93-96.

123. Shen, M. (2014). Earthquake information study for paleo-dammed lake at Minjiang River upstream, Chengdu University of Technology, Chengdu, Master thesis, Pp.1-119 (in Chinese).

124. Sieh, K. E. (1978). Prehistoric large earthquakes produced by slip on the San Andreas Fault at Pallett Creek, California, Journal of Geophysical Research: Solid Earth. 83, 3907-3939.

125. Sims, J. D. (1973). Earthquake-induced structures in sediments of Van Norman Lake, San Fernando, California, Science. 182(4108): 161-163.

126. Sims, J. D. (1975). Determining earthquake recurrence intervals from deformational structures in young lacustrine sediments, Tectonophysics. 29, 141152.

127. Song, X., Zhang, Y., Shan, X., Liu, Y., Gong, W., Qu, C (2019). Geodetic observations of the $2018 \mathrm{mw} 7.5$ sulawesi earthquake and its implications for the kinematics of the Palu fault, Geophysical Research Letters. doi/10.1029/2019GL082045.

128. Stirling, M., Goded, T., Berryman, K., Litchfield, N (2013). Selection of earthquake scaling relationships for seismic-hazard analysis, Bulletin of the Seismological Society of America. 103(6): 2993-3011.

129. Su, D. C., Qiao, X. F. (2018). Thixotropic deformation features of cohesive sediments triggered by palaeoearthquakes, Journal of Palaeogeography. 20(4): 609-622 (in Chinese with English abstract).

130. Suter, F., Martínez, J. I., Vélez, M. I. (2011). Holocene soft-sediment deformation of the Santa Fe-Sopetrán Basin, northern Colombian Andes: Evidence for pre-Hispanic seismic activity, Sedimentary Geology. 235,188-199.

131. Sutherland, R., Eberhart-Phillips, D., Harris, R. A., Stern, T., Beavan, J., Ellis, S., Henrys, S., Cox, S., Norris, R. J., Berryman, K. R., Townend, J., Bannister, S., Pettinga, J., Leitner, B., Wallace, L., Little, T. A., Cooper, A. F., Yetton, M., Stirling, M (2007). Do great earthquakes occur on the Alpine fault in central south Island, New Zealand?, A continental plate boundary: tectonics at South Island, New Zealand. 235-251.

132. Tang, M. Y., Jing, L., Shao, Y. X., Peng, W., Yuan, Z. D. (2015). Analysis about the minimum magnitude earthquake associated with surface ruptures. Seismology \& Geology. 37(4): 1193-1214 (in Chinese with English abstract). 
133. Tian, H. S., Zhang, S. H., Zhang, A. S. (2016). Test investigation on liquefied deformation structure in saturated lime-mud composites triggered by strong earthquakes, Acta Geologica Sinica (English Edition). 90(6): 2008-2021.

134. Trifunac, M. D., Brady, A. G. (1975). On the correlation of seismic intensity scales with the peaks of recorded strong ground motion, Bulletin of the Seismological Society of America. 65, 139-162.

135. Tuttle, M. P., Hartleb, R., Wolf, L., Mayne, P. W. (2019). Paleoliquefaction studies and the evaluation of seismic hazard, Geosciences. 9(7): 1-61.

136. Valera, J. E., Traubenik, M. L., Egan, J. A., Kaneshiro, J. Y. (1994). A practical perspective on liquefaction of gravels. In S. Prakash and P. Dakoulas (Editors), Ground failures under seismic conditions, American Society of Civil Engineers Geotechnical, Special Publication. 44, $241-257$.

137. van Loon, A. J. (2009). Soft-sediment deformation structures in siliciclastic sediments: an overview, Geologos. 15, 3-55.

138. van Loon, A, J., Pisarska-Jamroży, M., Nartišs, M., Krievāns, M., Soms, J (2016). Seismites resulting from high-frequency, high-magnitude earthquakes in Latvia caused by Late Glacial glacio-isostatic uplift, Journal of Palaeogeography. 5(4): 363-380.

139. Vandenberghe, J. (1992). Cryoturbations: a sediment structural analysis, Permafrost \& Periglacial Processes. 3, $343-351$.

140. Wang, J., Jin, Z., Hilton, R. G., Zhang, F., Densmore, A. L., Li, G., West, A. J. (2015). Controls on fluvial evacuation of sediment from earthquake-triggered landslides, Geology. 43(2): 115-118.

141. Wang, L. S., Yang, L. Z., Wang, X.Q., Duan, L. P. (2005). Discovery of huge ancient dammed lake on upstream of Minjiang River in Sichuan, China, Journal of Chengdu University Technology: Science囚Technology Edition. 32(1): 1-11 (in Chinese with English abstract).

142. Wang, P., Zhang, B., Qiu, W., Wang, J (2011). Soft-sediment deformation structures from the Diexi paleo-dammed lakes in the upper reaches of the Minjiang River, east Tibet, Journal of Asian Earth Sciences. 40(4): 865-872.

143. Wang, W., Godard, V., Liu-Zeng, J., Scherler, D., Xu, C., Zhang, J., Xie, K., Bellier, O., Ansberque, C., Sigoyer, J., ASTER, T (2017). Perturbation of fluvial sediment fluxes following the 2008 Wenchuan earthquake, Earth Surface Processes and Landforms. 42(15): $2611-2622$.

144. Wells, D. L., Coppersmith, K. J. (1994). New empirical relationships among magnitude, rupture length, rupture width, rupture area, and surface displacement. Bulletin of the Seismological, Society of America. 84, 974-1002.

145. Weltje, G. J. (1997). End-member modeling of compositional data: numerical-statistical algorithms for solving the explicit mixing problem, Mathematical Geology. 29(4): 503-549.

146. Wetzler, N., Marco, S., Heifetz, E (2010). Quantitative analysis of seismogenic shear-induced turbulence in lake sediments, Geology. 38(4): $303-306$.

147. Xu, C., Xu, X., Yao, X., Dai, F (2014). Three (nearly) complete inventories of landslides triggered by the May 12, 2008 Wenchuan Mw 7.9 earthquake of China and their spatial distribution statistical analysis, Landslides. 11(3): 441-461.

148. Xu, H. Y., Jiang, H. C., Yu, S., Yang, H., Chen, J (2015). OSL and pollen concentrate ${ }^{14} \mathrm{C}$ dating of dammed lake sediments at Maoxian, east Tibet, and implications for two historical earthquakes in AD 638 and 952, Quaternary International. 371, 290-299.

149. Xu, X. W., Wen, X. Z., Yu, G. H., Chen, G. H., Klinger, Y., Hubbard, J., Shaw, J (2009). Coseismic reverse-and oblique-slip surface faulting generated by the $2008 \mathrm{Mw} 7.9$ Wenchuan earthquake, China, Geology. 37, 515-518.

150. Xu, X. W., Chen, G. H., Wang, X. Q., Chen, L. C., Ren, Z. K., Xu, C., Wei, Z. Y., Lu, R. Q., Tang, X. B., Dong, S. P., Shi, F (2017). Discussion on seismogenic structure of Jiuzhaigou earthquake and its implication for current strain state in the southeastern Qinghai-Tibet Plateau, Chinese Journal of Geophysics. 60(10):4018-4026 (in Chinese with in English abstract).

151. Yang, W., Qi, W., Zhou, J (2018). Decreased post-seismic landslides linked to vegetation recovery after the 2008 Wenchuan earthquake, Ecological indicators. 89, 438-444.

152. Yang, X. P., Wu, G., Chen, L. C., Li, C. Y., Chen, X. L. (2016). The seismogenic structure of the April 25, $2015 \mathrm{Mw} 7.8 \mathrm{Nepal}$ earthquake in the southern margin of Qinghai-Tibetan Plateau, Chinese Journal of Geophysics. 59(7):2528-2538 (in Chinese with English abstract).

153. Yasuda, S., Verdugo, R., Konagai, K., Sugano, T., Villalobos, F., Okamura, M., Tobita, T., Torres, A., Towhata, I (2010). Geotechnical damage caused by the 2010 Maule, Chile earthquake, Issmge Bulletin. 4 (2):16-27.

154. Youd, T. L. (1977). Discussion of 'Brief review of liquefaction during earthquakes in Japan' by E. Kuribayashi and T. Taatsuoka, Soils Foundation. 17, 82-85.

155. Zhang, F., Jin, Z., West, A. J., An, Z., Hilton, R. G., Wang, J., Li, G., Densmore, A., Yu, J., Qiang, X., Sun, Y., Li, L., Gou, L., Xu, Y., Xu, X., Liu, X., Pan, Y., You, C (2019). Monsoonal control on a delayed response of sedimentation to the 2008 Wenchuan earthquake, Science advances. 5(6):7110.

156. Zhang, Y. Q., Li, J., Li, H, L., Li, J. H. (2016). Reinvestigation on seismogenic structure of the 1933 Diexi Ms7.5 earthquake, eastern margin of the Tibetan Plateau, Geological Review. 62, 267-276 (in Chinese with English abstract).

157. Zhang, Y. S., Yang, Z. H., Guo, C. B., Wang, T., Wang, D. H., Du, G. L. (2017). Predicting landslide scenes under potential earthquake scenarios in the Xianshuihe fault zone, Southwest China, Journal of Mountain Science. 14(7): 1262-1278.

158. Zhang, Y., Cheng, Y., Yin, Y., Lan, H., Wang, J., Fu, X (2014). High-position debris flow: a long-term active geohazard after the Wenchuan earthquake, Engineering geology. 180, 45-54.

159. Zhong, N. (2017). Earthquake and provenance analysis of the lacustrine sediments in the upper reaches of the Min River during the Late Pleistocene, Institute of Geology, China Earthquake Administration, Beijing, Doctoral thesis, Pp. 1-181 (in Chinese).

160. Zhong, N., Jiang, H. C., Liang, L. J., Xu, H.Y., Peng, X. P. (2017). Paleoearthquake researches via soft sediment deformation of load, ball-and-pillow structure: a review, Geological Review. 63, 719-738 (in Chinese with English abstract). 
161. Zhong, N., Jiang, H. C., Li, H. B., Xu, H. Y., Shi, W., Zhang, S. Q., Wei, X. T. (2019). Last deglacial soft-sediment deformation at Shawan on the eastern Tibetan plateau and implications for deformation processes and seismic magnitudes, Acta Geological Sinica (English edition). 93(2): 430-450.

162. Zhong, N., Li, H. B., Jiang, H. C., Lu, H. J., Zheng, Y., Han, S., Ye, J. C. (2020a). Typical soft-sediment deformation structures induced by freeze/thaw cycles: a case study of Quaternary alluvial deposits in the northern Qiangtang Basin, Tibetan Plateau, Acta Geological Sinica (English edition). 94(1): 176-188.

163. Zhong, N., Jiang, H.C., Li, H. B., Xu, H. Y., and X. L. Huang (2020b). The genetic types of soft sediment deformation structures and their characteristics in the fluvial-lacustrine sediments $₫$ Eastern Tibetan Plateau, Acta Geoscientica Sinica. 94(1): 23-36 (in Chinese with English abstract).

164. Zhong, N., Jiang, H. C., Li, H. B., Xu, H. Y., Liang, L. J., Shi, W. (2020c). End member inversion of Xinmocun lacustrine sediment in the upper reaches of the Min River and its recorded tectonic and climate events, Acta Geological Sinica. 94(3): 968-981 (in Chinese with English abstract).

\section{Figures}

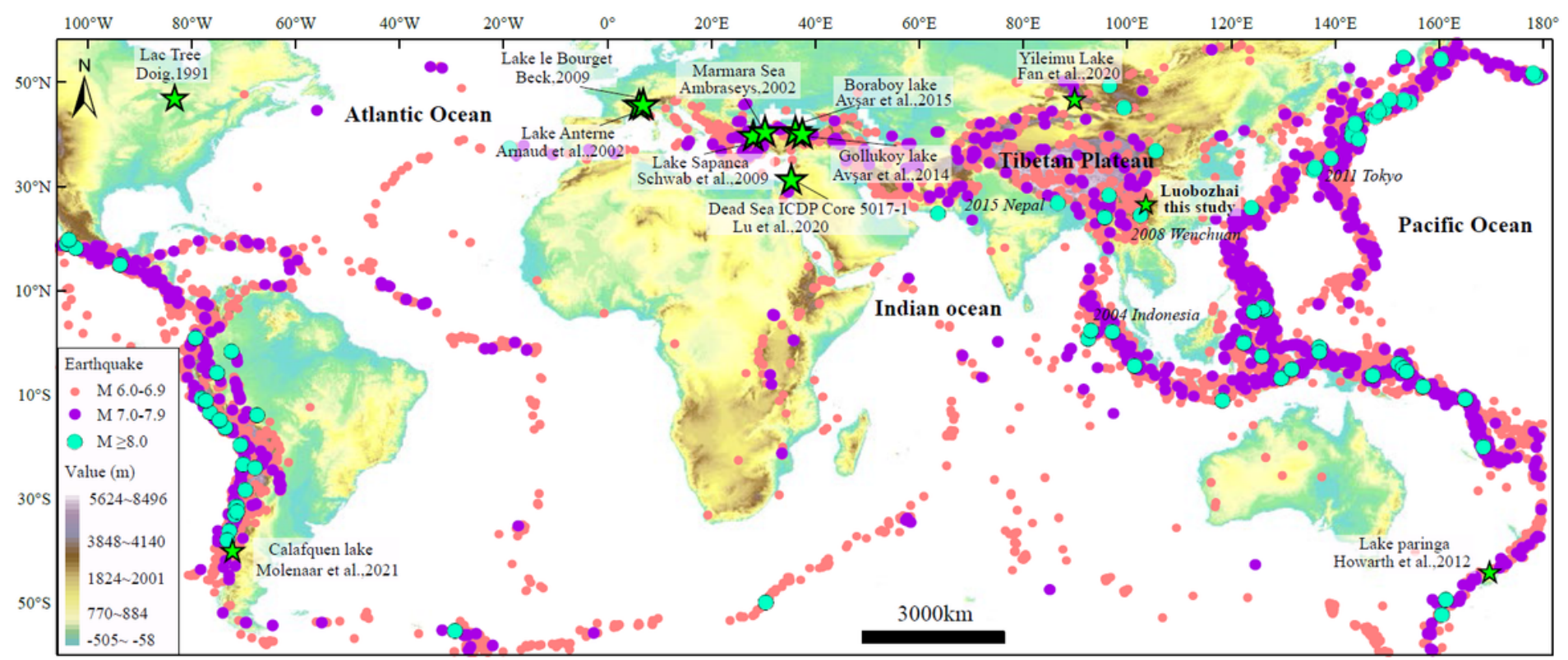

Figure 1

Spatial distributions of relationship between soft sediment deformation structure or rapidly deposited sand layer thicknesses and earthquake magnitude, and earthquakes with magnitude over 6.0 from 1900 to 2021 all over the world邓data sources from http://earthquake.usgs.gov). 


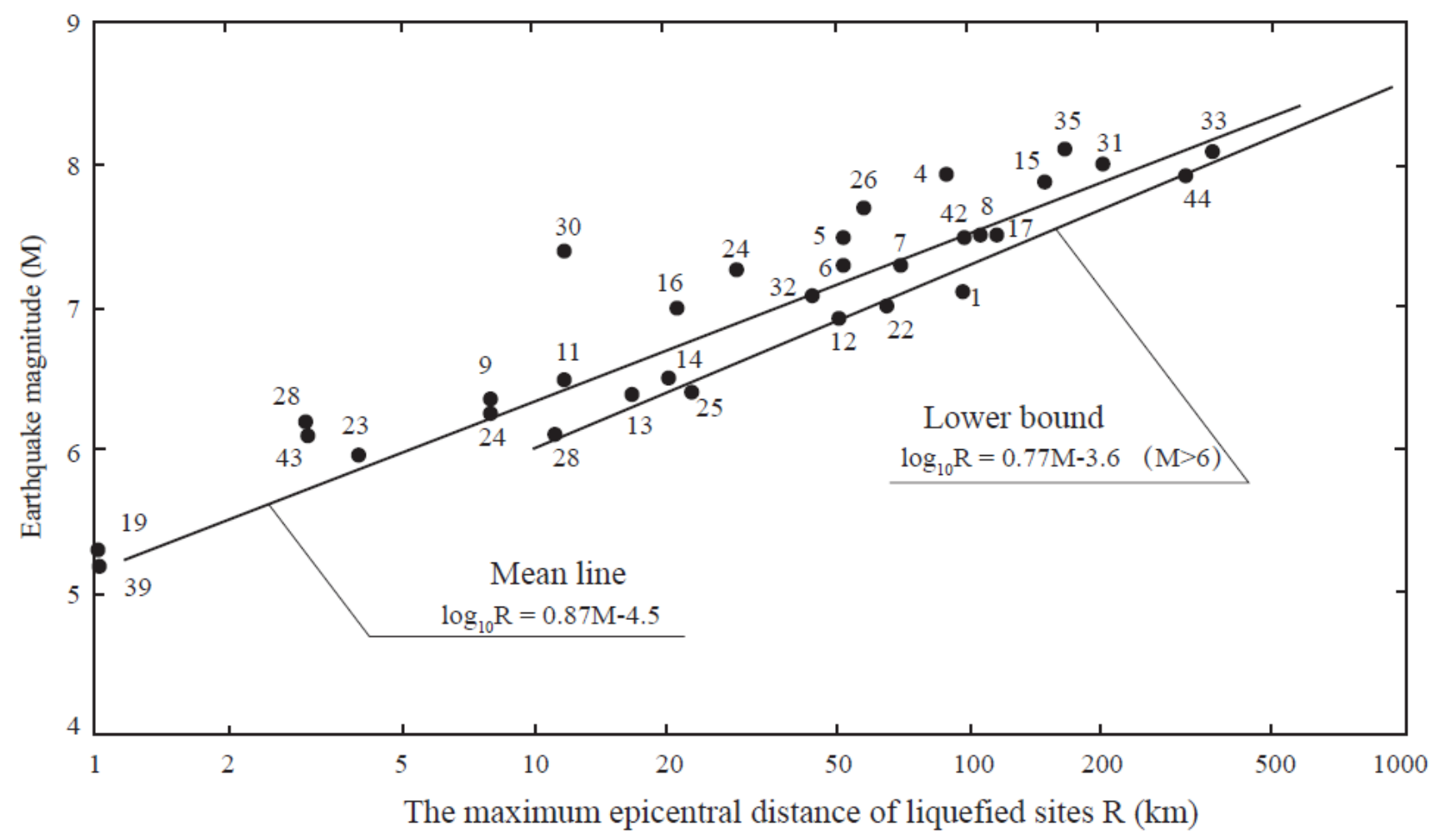

\section{Figure 2}

Relationship between the maximum epicentral distance of liquefied sites R and magnitude M (modified from Kuribayashi and Tatsuoka, 1975). Numbers represent earthquakes which induced liquefaction in Japan during the years 1872-1968. The mean line is for all dates, and the lower bound is for Mヌ6.

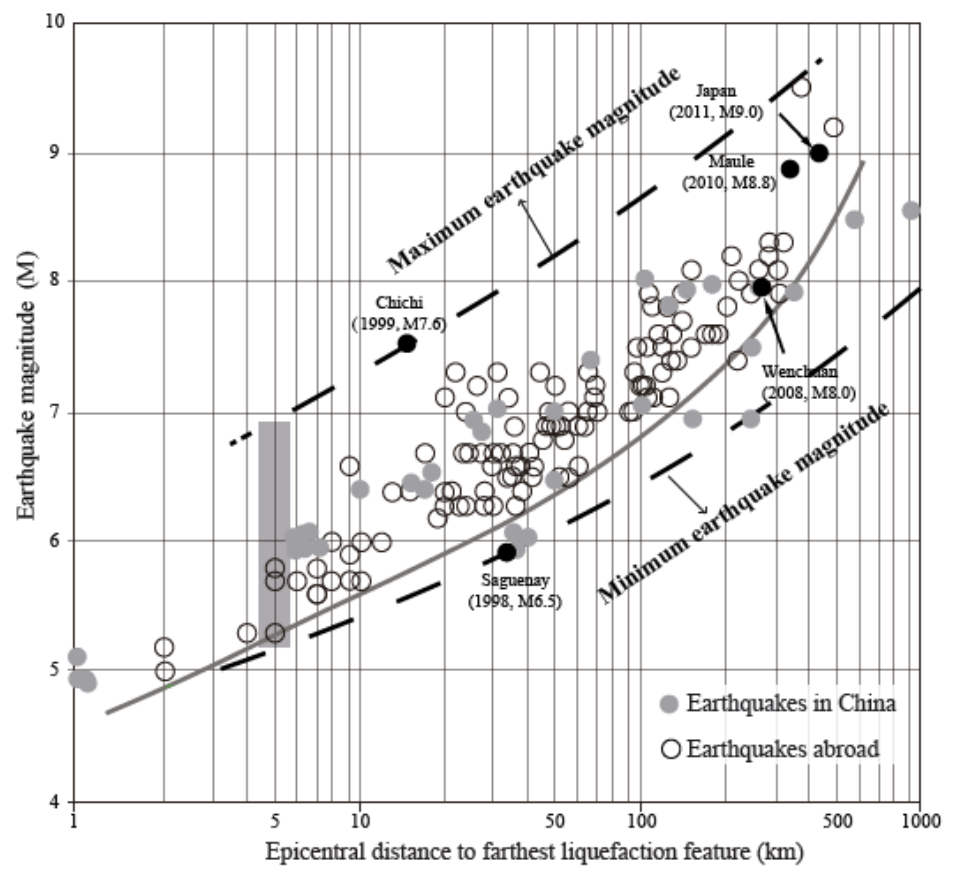

\section{Figure 3}

Relationship between earthquake magnitude and the epicentral distance to farthest liquefaction feature (modified from Qiao et al., 2017). The gray rectangle indicates the recorded liquefaction in the Lake Lisan and Luobozhai section ( $M=5.2-6.8)$. 


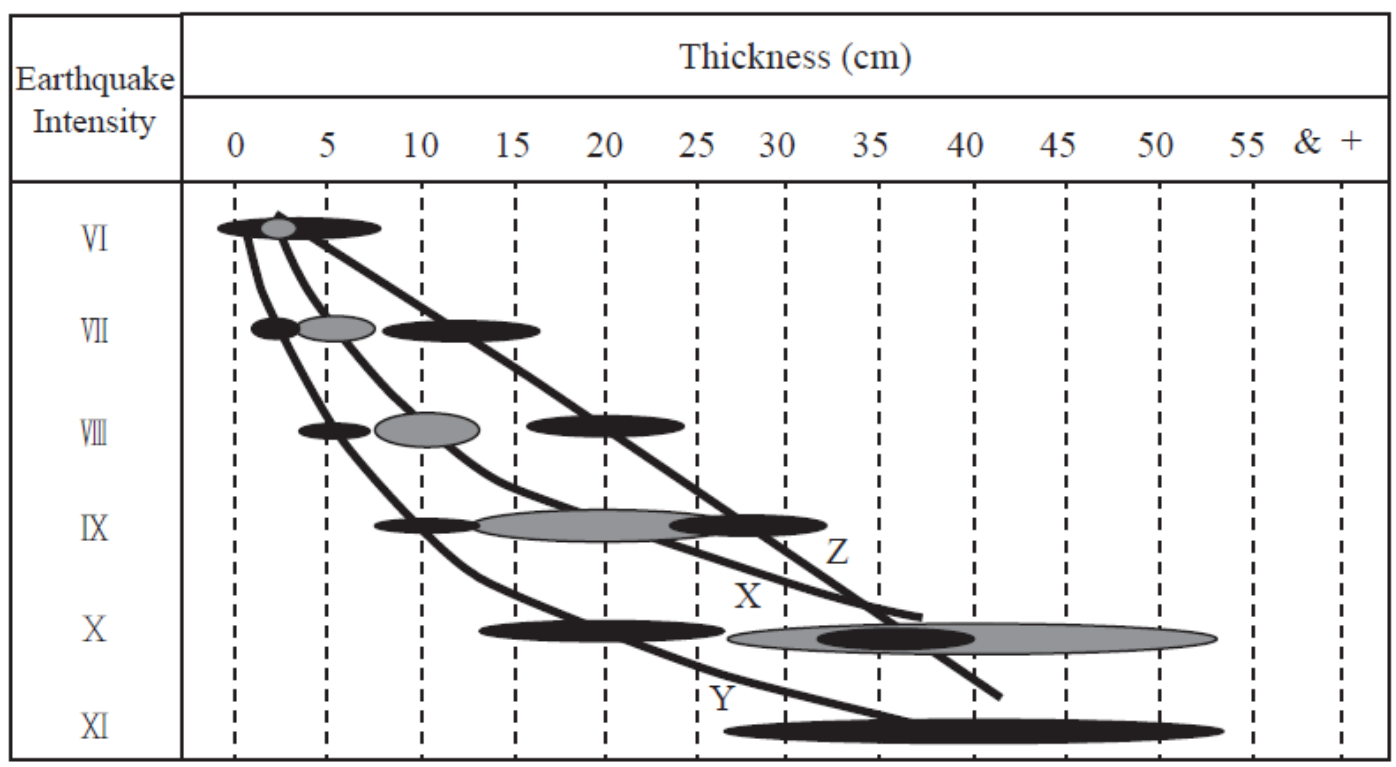

\section{Figure 4}

Historical seismicity of Quito (Ecuador) and the attribution of seismic shaking to the paleoseismic levels (modified from Hibsch et al., 1997). The X scale is based on by historical seismicity data. The $\mathrm{Y}$ and $\mathrm{Z}$ scales both consider a multiplicative factor of $\mathrm{X}$ based on observations of paleo-seismic horizons in lacustrine deposits in California (Sims, 1975) and on mathematical relations between horizontal ground acceleration and seismic shaking (Trifunac and Brady, 1975).

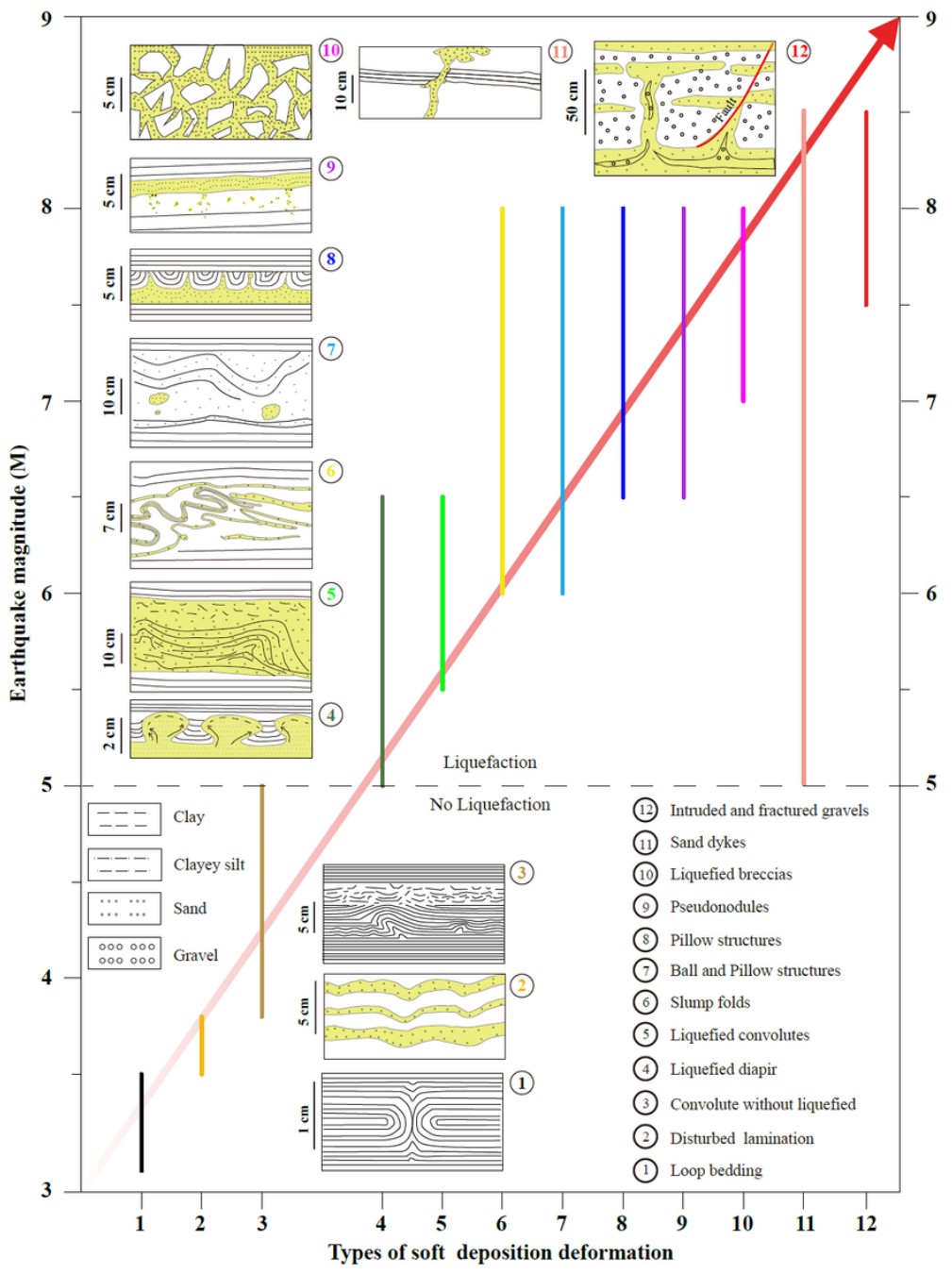

Figure 5 
(a)

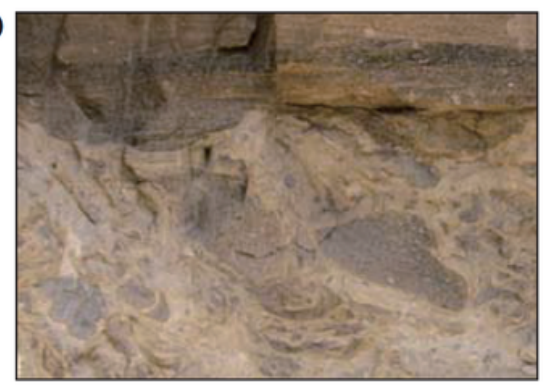

(b)

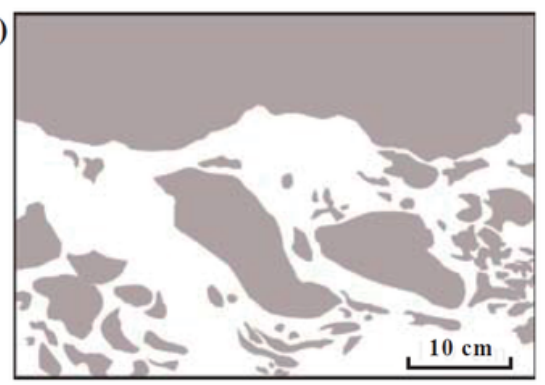

Figure 6

Correlation of soft sediment deformation structures with changes in sedimentary index values (grain size and magnetic susceptibility) from Xinmocun, east Tibet (Jiang et al., 2014).
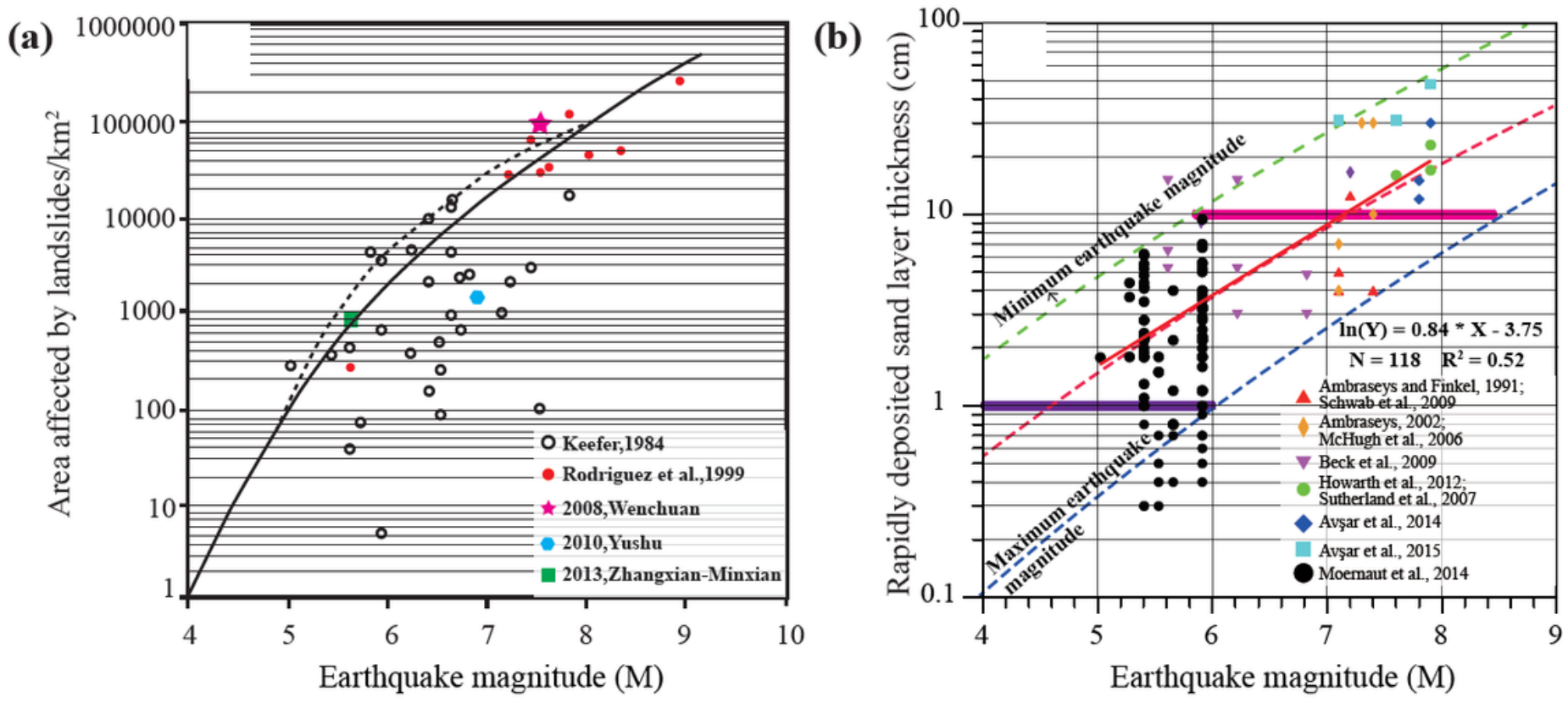

Figure 7

(a) Area affected by landslides during earthquakes of different magnitudes; (b) suggested linear correlation between rapidly deposited sand layer thicknesses and earthquake magnitudes of the responsible earthquakes. 
(a)

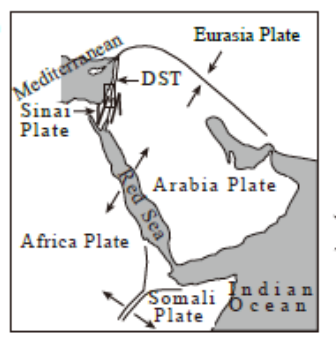

(b)

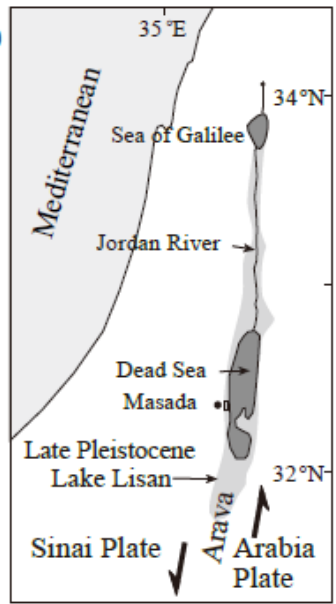

(c)
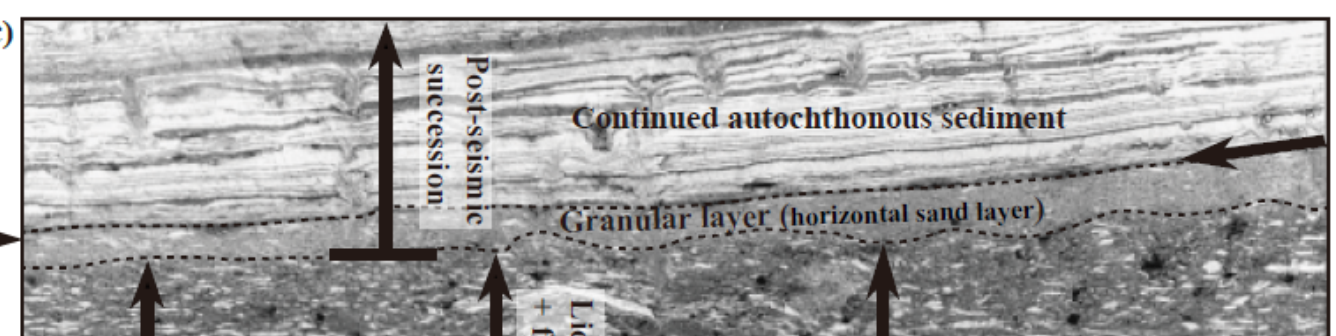
ton? $8=$ $3-1-2=$

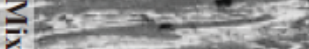
ast. $1+3 x-5$

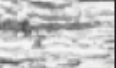

东

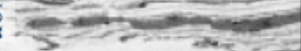

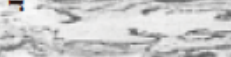

atrence
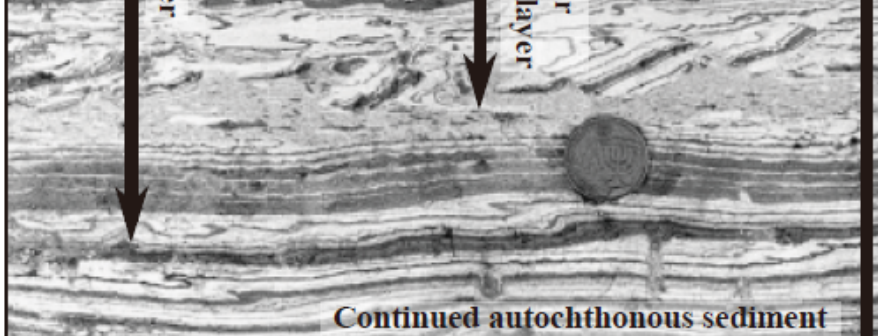

Continued autochthonous sediment -
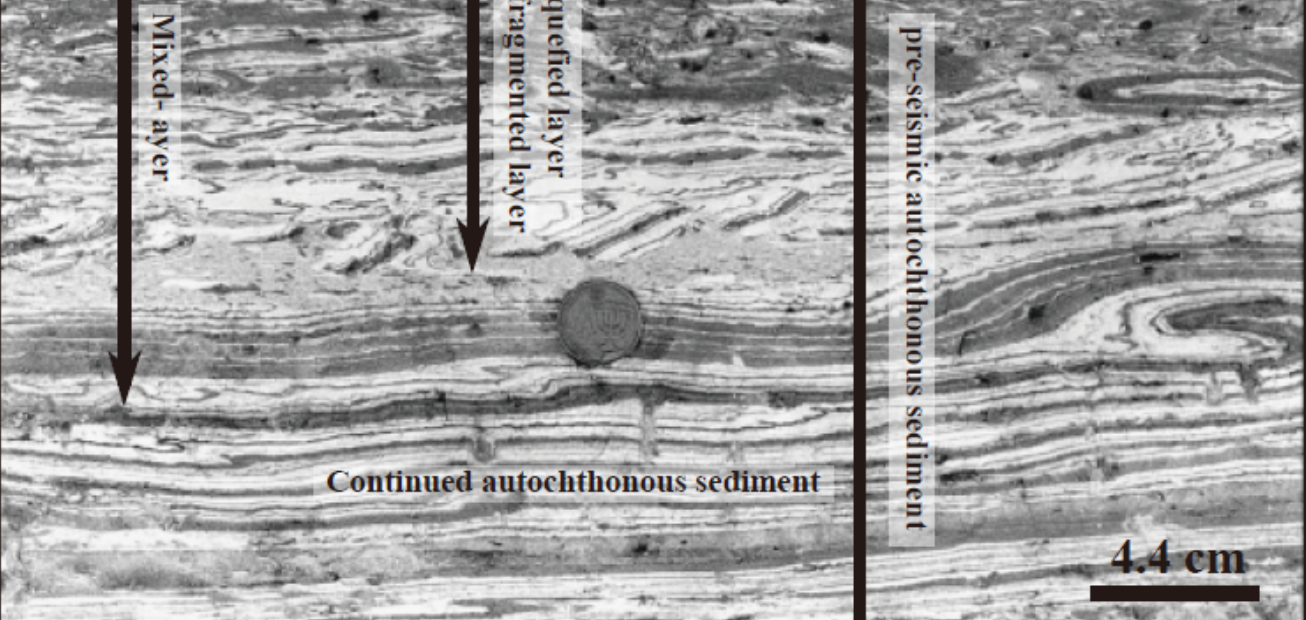

\section{Figure 8}

(a-b) Tectonic plates in the Middle East. The Dead Sea Transform (DST) transfers the opening of the Red Sea to the East Anatolian Fault and the TaurusZagros collision zone (modified from Marco and Agnon, 2005). (c) Elements of a typical intraclast breccia layer overlying a disrupted sequence. A typical seismics-related deposit in late-Pleistocene fan delta sediments which overlie laminated layers shows a gradual upwards transition from the folded strata of Masada near the lacustrine Lisan Formation in Israel, through a fragment-supported texture, to a matrix-supported texture at the top (modified from Marco and Agnon, 1995). 


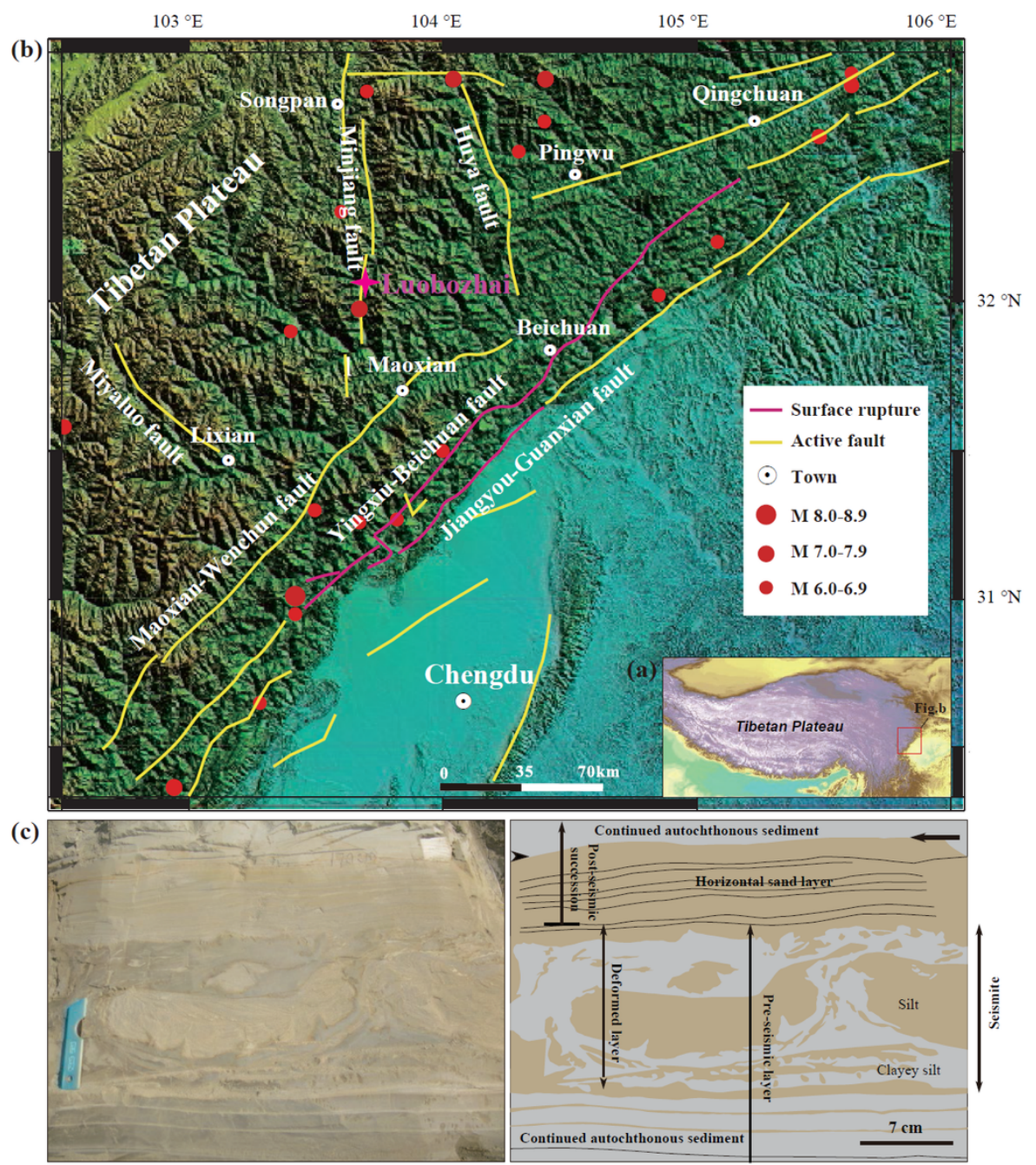

\section{Figure 9}

(a) DEM of the study region illustrating the geomorphology and drainage system, (b) and the location of the Luobozhai section (purple star). The red solid circles show the seismicity between 1900 and 2012 (modified from Jiang et al., 2014). Surface ruptures and active faults are after Xu et al. (2009). (c) A typical liquefied diapir in the Luobozhai lacustrine sediment was induced by an earthquake during the late-Quaternary, in the upper reaches of the Minjiang River, east Tibet. 